\title{
Dietary Flaxseed Meal and Chromium: a Nutritional Intervention in Broiler Chicken to Study the Prospective Growth Performance, Tissue Lipid Composition and Metabolism, Health Indices, and Serum Lipid Chemistry
}

Nasir Akbar Mir ( $\square$ nasirakbar129@gmail.com )

ICAR- Central Avian Research Institute https://orcid.org/0000-0003-0929-0713

Praveen K. Tyagi

Central Avian Research Institute

Jubeda Begum

Govind Ballabh Pant University of Agriculture \& Technology College of Veterinary \& Animal Sciences

Kapil Dev

Central Avian Research Institute

Avishek Biswas

Central Avian Research Institute

Pramod K. Tyagi

Central Avian Research Institute

Divya Sharma

Central Avian Research Institute

Chandra Deo

Central Avian Research Institute

A.B. Mandal

Central Avian Research Institute

\section{Research}

Keywords: $₫-3$ fatty acids, Antioxidant enzymes, Flaxseed, Growth performance, Health indices, Lipid metabolism

Posted Date: June 15th, 2020

DOI: https://doi.org/10.21203/rs.3.rs-35345/v1 
License: (c) (i) This work is licensed under a Creative Commons Attribution 4.0 International License. Read Full License 
Dietary flaxseed meal and chromium: A nutritional intervention in broiler chicken to study the prospective growth performance, tissue lipid composition and metabolism, health indices, and serum lipid chemistry

Running title: Broiler chicken nutrition and lipid deposition

6 Nasir Akbar Mir*a, Praveen K. Tyagi ${ }^{\mathrm{a}}$, Jubeda Begum ${ }^{\mathrm{b}}$, Kapil Dev ${ }^{\mathrm{a}}$, Avishek Biswas ${ }^{\mathrm{a}}$, Pramod K. Tyagi ${ }^{a}$, Divya Sharma ${ }^{a}$, Chandra Deo ${ }^{\mathrm{a}}$, A. B. Mandal ${ }^{\mathrm{a}}$

${ }^{\mathrm{b}}$ Govind Ballabh Pant University of Agriculture \& Technology, College of Veterinary \& Animal Sciences, Pantnagar, India

*Corresponding Author: Nasir Akbar Mir. E-mail: nasirakbar129@gmail.com 


\section{Abstract}

13 Background: Flaxseed in a richest terrestrial source of $\omega-3$ fatty acid - alpha-linolenic acid

14 (ALA) which can be incorporated in chicken meat when it is included in chicken ration. ALA

15 can further be acted up on by desaturating enzymes to generate PUFA such as EPA and DHA

16 which increase the health value of chicken meat. However, dietary flaxseed results in concurrent

17 increase in lipid oxidation due higher unsaturation and negative impact on chicken growth performance. These negative effects of flaxseed feeding can be reversed by chromium supplementation in broiler chicken. Thus, this study investigated growth performance and efficiency, lipid composition, lipid metabolism, health indices, and serum lipid chemistry of broiler chicken fed flaxseed meal (FSM) and chromium (Cr).

22 Results: Feeding of 100 g FSM exerted negative effects on the growth performance during starter phase only (0-3 weeks) and overall growth efficiency parameters in broiler chicken, whereas, Cr supplementation reversed these negative effects. $100 \mathrm{~g}$ FSM reduced abdominal fat in chicken and $\mathrm{Cr}$ supplementation linearly decreased it with minimum at $1.5 \mathrm{mg} \mathrm{Cr} / \mathrm{kg}$ diet. Feeding of $100 \mathrm{~g}$ FSM favourably improved the activities of lipid metabolism enzymes which resulted in improved fatty acid profile and health indices of chicken meat. No significant effect of Cr supplementation was observed on lipid metabolism, fatty acid profile, and health indices of chicken meat. 100 g FSM decreased serum total cholesterol, triglyceride, cardiac risk ratio,

30 atherogenic coefficient, and atherogenic index of plasma, whereas, $\mathrm{Cr}$ supplementation

31 decreased these parameters linearly with increasing levels. Antioxidant enzyme activities and

32 lipid peroxidation were increased by FSM, whereas, Cr supplementation linearly decreased them

33 with increasing levels; and inverse trend was observed in serum HDL cholesterol levels.

34 Conclusions: Feeding of 100 g FSM exert negative effects on growth performance of young chicken (0-3 weeks), favourably alter lipid metabolism which results in improved fatty acid 
profile and health indices of chicken meat. It improves the serum lipid profile and atherogenic indices in broiler chicken, but negatively affects the oxidative stability of lipids. However, $\mathrm{Cr}$ supplementation at the rate of $1.5 \mathrm{mg} / \mathrm{kg}$ diet successfully overcomes these negative effects of FSM feeding on growth performance and lipid oxidative stability.

40 Keywords: $\omega-3$ fatty acids; Antioxidant enzymes; Flaxseed; Growth performance; Health indices; Lipid metabolism

\section{Background}

43 Chromium (Cr), an essential trace element required for normal carbohydrate and lipid metabolism in humans and animals [1], has generated considerable interest in its role in animal nutrition. In the field of animal nutrition, there are emerging evidences which suggest that dietary $\mathrm{Cr}$ requirement of poultry may be higher than the amount found in a typical corn soybean meal diet [2]. Poultry feeds of plant origin are poor in $\mathrm{Cr}$ and poultry birds may exhibit $\mathrm{Cr}$ deficiency [3] which may reflect badly on their growth performance. The Cr deficiency disrupts the normal carbohydrate, protein, and lipid metabolism and reduces the insulin sensitivity in peripheral tissues which results in impairment of growth rate in broiler chicken [4]. Cr supplementation is supposed to improve the growth performance of broiler chicken by apparent involvement in gene expression, whereby it binds nuclear chromatin which results in increase in number of initiation sites and in turn enhances RNA synthesis [5]. Improved growth performance [6], carcass yield, and reduced abdominal fat $[3,4,6]$ was reported in broiler chicken supplemented with dietary Cr. Cr supplementation in broiler chicken is an interesting aspect of animal nutrition from physiology and muscle growth point of view because Cr potentiates the effects of insulin which is an anabolic hormone involved in regulation of growth [7]. Compared to ruminants very scanty literature pertaining to $\mathrm{Cr}$ supplementation in broiler chicken is available [5]. Thus, because of

59 this insufficient and inconclusive literature on $\mathrm{Cr}$ supplementation and its bioavailability there 60 are no dietary $\mathrm{Cr}$ recommendations for poultry. 

have been observed, because of newly evolved food and eating habits of people, which reflects badly on their health and involves high treatment costs [8]. Health professionals worldwide recommend the intake of $\omega-3$ polyunsaturated fatty acids (PUFA) such as alpha-linolenic acid (ALA), eicosapentaenoic acid (EPA) and docosahexaenoic acid (DHA) to help contain or prevent cardio and cerebro vascular diseases in humans $[9,10]$. In the long run, use of marine sources for enrichment of human diets with EPA and DHA is an unsustainable solution which creates a negative impact on global fish stocks and aquaculture [11]. Under such circumstances flaxseed feeding in chicken, a richest terrestrial source of $\omega-3$ fatty acids, is the most valuable nutritional strategy for developing the value-added poultry meat with improved health indices [12]. In monogastrics, such as chicken, a strong relationship exists between the dietary fatty acids and those deposited in tissues because no biohydrogenation of dietary unsaturated fatty acids (UFA) occur in monogastric animals [13]. This makes chicken meat most suitable and an easy target for $\omega$-3 fatty acid fortification $[8,11,12,14]$. The health indices of food items are measured in terms of relative abundance of SFA, UFA, PUFA, and $\omega-6: \omega-3$ PUFA ratio. The $\omega$-3 fatty acid such as alpha-linolenic acid (ALA) abundantly present in flaxseed can be converted into long chain PUFA such as EPA, DPA, DHA by the desaturating enzymes [12]. Though, flaxseed feeding in chicken increases the omega-3 fatty acid content of meat [8, $11,14]$ and reduces abdominal fat [15] it exerts negative effects on the growth performance of broiler chicken $[16,17]$. Also, an increased UFA content in broiler chicken meat makes it more prone to lipid peroxidation. However, $\mathrm{Cr}$ has shown antioxidant properties which alleviate the

82 negative effects of oxidative stress and confer protection against lipid peroxidation [18, 19].

83 Also, $\mathrm{Cr}$ potentiates the insulin sensitivity which reduces the fat and enhances the protein content 84 in broiler chicken [3]. The body antioxidant status is measured by the activities of different 
antioxidant enzymes such as superoxide dismutase (SOD), catalase, glutathione peroxidase (GSH-Px) and glutathione reductase (GR). Furthermore, $\mathrm{Cr}$ also influences the metabolism of cholesterol and triglycerides [20] by which it exerts hypocholesterolemic and hypolidemic effects. Thus, dietary Cr supplementation offers a new approach to increase meat quality of animals [21]. Thus, this study was designed to analyse the effects of flaxseed meal (FSM) feeding and $\mathrm{Cr}$ supplementation on the growth performance, carcass characteristics, lipid composition, lipid metabolism, sensory quality and health indices of meat, serum antioxidant and lipid chemistry in broiler chicken with a hypothesis that in chicken the lipid profile and health indices are improved by flaxseed feeding, and the Cr supplementation alleviates the consequent lipid peroxidation problem arising out of flaxseed meal feeding.

\section{Methods}

The experimental procedures carried out in the study were approved by the Institutional Animal

97 Ethics Committee (IAEC) following the guidelines of "Committee for the Purpose of Control and Supervision of Experiments on Animals (CPCSEA) 2012”' established under the 'Prevention of Cruelty to Animals Act 1960' of Indian Penal Code (Approval number 604/09/bc/CPCSEA).

\section{Experimental design, birds, husbandry conditions, and diets}

101 The experimental trial was conducted on 300 day-old commercial broiler chicken, procured from

102 the institutional hatchery, to investigate the effects of dietary FSM and Cr supplementation on 103 their performance, lipid deposition, meat quality, and serum biochemistry. The birds were 104 randomly assigned to five dietary treatments, having six replicates (cages) per treatment with 10 105 birds in each replicate. The birds were housed in specially designed battery brooder cages for six 106 weeks with ad libitum provision of mash feed and fresh water on daily basis. The birds were 107 provided $23 \mathrm{~h}$ light first 3 days followed by a decrease of $1 \mathrm{~h}$ per day until it reached a $18 \mathrm{~h}$ light 108 period which was continued until $42^{\text {nd }}$ day. The initial cage temperature of $95{ }^{\circ} \mathrm{F}$ was reduced by 
$1095{ }^{\circ} \mathrm{F}$ every week to provide thermo-comfort environment to the birds. The FSM and Cr were

110 employed to formulate five iso-caloric and iso-nitrogenous dietary treatments viz. T1 (0 g FSM

$111 \& 0 \mathrm{mg} \mathrm{Cr} / \mathrm{kg}$ diet), T2 (100 g FSM \& $0 \mathrm{mg} \mathrm{Cr} / \mathrm{kg}$ diet), T3 (100 g FSM \& $0.5 \mathrm{mg} \mathrm{Cr} / \mathrm{kg}$ diet),

$112 \mathrm{~T} 4$ (100 g FSM \& $1.0 \mathrm{mg} \mathrm{Cr} / \mathrm{kg}$ diet), and T5 (100 g FSM \& $1.5 \mathrm{mg} \mathrm{Cr} / \mathrm{kg}$ diet). The inclusion

113 level of $100 \mathrm{~g}$ FSM was standardized by preliminary trials. The ingredients and nutrient

114 composition of each dietary treatment is shown in Table 1. The organic $\mathrm{Cr}$ in the form of 115 chromium picolinate was used for Cr supplementation.

\section{Growth performance, mortality, and cost economics}

117 The body weight of individual birds were recorded on weekly basis and feed intake was 118 calculated daily on replicate basis by taking the difference of feed offered and residual feed. The 119 body weight gain (BWG), feed intake, and feed conversion ratio (FCR) were calculated for 0-3 120 week, 4-6 week, and 0-6 week durations. The mortality of the birds was recorded as and when it 121 occurred. The growth efficiency parameters viz. production efficiency factor (PEF), protein 122 efficiency ratio (PER), and energy efficiency ratio (EER) were calculated as follows [22]:

126 Cost of feed involved in the production of broiler chicken was calculated in terms of per kg live

127 weight gain and per kg meat yield based on prevailing market price of the feed ingredients and 128 expressed as percentage change in cost in each treatment group with respect to the control diet 129 (T1).

\section{Carcass characteristics and sensory evaluation}

131 At the end of six weeks feeding trial 12 birds from each dietary treatment (1 male and 1 female

132 per replicate) were selected randomly and sacrificed after 12 hours of fasting with ad libitum 133 drinking water for evaluation of carcass characteristics and sensory evaluation of meat. The 
134 subjective colour and odour measurements were recorded on fresh meat as well as after 30 days

135 of refrigerated storage. Since poultry furnish white meat, for better visual scores 5- point

136 descriptive colour scale was used $(5=$ white, $4=$ pale red, $3=$ reddish pale, $2=$ reddish grey, 1

$137=$ pale grey), while, 5 - point scale for odour was; $5=$ very pleasant, $4=$ pleasant, $3=$ moderately

138 pleasant, $2=$ moderately unpleasant, $1=$ very unpleasant. In both cases $5=$ extremely desirable

139 and $1=$ extremely undesirable. Cooked meat samples were also subjected to sensory evaluation

140 in which uniform size samples from each treatment group were steam cooked at 15 lbs pressure

141 for 15 minutes and served to semi trained judges of test panel $(n=12)$. Judges were requested to

142 make their opinion based on 8 point descriptive scale where $8=$ extremely desirable and $1=$

143 extremely undesirable [23].

\section{Sample collection}

145 The birds sacrificed for carcass trait study were used for collection of breast and thigh muscle

146 samples without skin for the study of fatty acid profile, fatty acid metabolism indices, and health

147 indices. Also, prior to sacrificing of birds blood samples were collected in non-heparinised tubes,

148 serum was harvested, and immediately stored at $-20{ }^{\circ} \mathrm{C}$ for the study of serum antioxidant 149 enzyme activities and other biochemical parameters detailed ahead in this section.

\section{Gas chromatography and fatty acid profile analysis}

151 For fatty acid profile analysis of meat and feed samples a standardized protocol is followed at 152 our research institute. Fatty acid methyl esters (FAMEs) were prepared directly from the feed, 153 breast, and thigh meat samples by using C13:0 ME internal standard (0.5 mg C13:0/ml methanol) 154 [24]. The FAMEs, prepared in hexane, were stored in Gas chromatograph (GC) vials and placed at $-20{ }^{\circ} \mathrm{C}$ until analysis. The fatty acid composition of the FAME was determined by capillary

156 Gas liquid chromatography on a CP-6173, $60 \mathrm{~m} \times 0.25 \mathrm{~mm} \times 0.20 \mathrm{~mm}$ capillary column (Varian)

157 installed on a Thermo Scientific Ceres 800 plus gas chromatograph fitted with an Automatic sampler AI3000, integrator and flame ionization detector. The initial oven temperature was 120 
$159{ }^{\circ} \mathrm{C}$, which was held for $5 \mathrm{~min}$. Then, subsequently the temperature was increased to $240{ }^{\circ} \mathrm{C}$ at a 160 rate of $2{ }^{\circ} \mathrm{C} / \mathrm{min}$, and held for $60 \mathrm{~min}$. Nitrogen was used as the carrier gas at a flow rate of 1

$161 \mathrm{ml} / \mathrm{min}$. The injector and the detector of GC were set at $260{ }^{\circ} \mathrm{C}$. The split ratio was $30: 1$. Fatty 162 acid standard purchased from Supelcon, Bellefonte- PA contained 37 different FAMEs and 0.5 $163 \mu \mathrm{l}$ was injected into GC to get the standard peaks. The fatty acids were identified by comparing 164 retention time of their peaks with the respective fatty acid methyl ester standards and were expressed as percentage of total fatty acids in feed, breast, and thigh samples.

\section{Fatty acid metabolism indices}

167 The fatty acids present in body are acted upon by various enzymes of lipid metabolism to produce 168 higher SFAs, monounsaturated fatty acids (MUFAs), and PUFAs. This fatty acid conversion 169 occurs predominantly in liver and the products get deposited in muscle tissues. This conversion 170 is measured in terms of certain indices by relating the percentage of products to the percentage 171 of their corresponding precursors in chicken meat. The enzyme activities in the production of

172
MUFAs was calculated as follows [25]:

$$
\begin{aligned}
& \Delta 9 \text { - DI (18): } \Delta 9 \text { - desaturase (18) index }=100[\text { C18:1/(C18: } 1+\text { C18:0) }] \\
& \Delta 9-\text { DI (16): } \Delta 9 \text { - desaturase (16) index }=100[\text { C16:1/(C16:1 + C16:0)] }
\end{aligned}
$$

Total DI $\Delta 9-$ desaturase index $=100[(\mathrm{C} 16: 1+\mathrm{C} 18: 1) /(\mathrm{C} 16: 1+\mathrm{C} 16: 0+\mathrm{C} 18: 1+\mathrm{C} 18: 0)]$

The enzyme activities in the conversion of myristic acid (C14:0) to palmitic acid (C16:0) and further to steric acid (C18:0) was measured in terms of thioesterase and elongase indices as follows [26]:

$$
\text { Elongase index }(\mathrm{EI})=\mathrm{C} 18: 0 / \mathrm{C} 16: 0
$$

$$
\text { Thioesterase index }(\mathrm{TI})=\mathrm{C} 16: 0 / \mathrm{C} 14: 0
$$

Similarly, the enzyme activities in the conversion of essential fatty acids (EFA), linoleic acid (LA) and ALA, into long chain PUFA was measured in terms of $\Delta^{5}+\Delta^{6}$ desaturase index as follows [27]: 


$$
\Delta^{5}+\Delta^{6} \text {-desaturase index }=100[(\mathrm{C} 20: 2 \omega-6+\mathrm{C} 20: 4 \omega-6+\mathrm{EPA}+\mathrm{C} 22: 5 \omega-3+\mathrm{DHA}) /
$$

$$
(C 18: 2 \omega-6(L A)+A L A+C 20: 2 \omega-6+C 20: 4 \omega-6+E P A+
$$

$$
\mathrm{C} 22: 5 \omega-3+\mathrm{DHA})]
$$

\section{Health indices of meat}

188 The modification in the fatty acid profile of chicken meat alters its health profile. Different 189 indicators or determinants of health profile are used to measure the health value of chicken meat.

190 The ratios of $\omega-3$ PUFA to $\omega-6$ PUFA, PUFA to SFA, MUFA to SFA, and UFA to SFA along 191 with saturation index (S/P), atherogenic index (AI), and thrombogenic index (TI) are considered 192 as health indices of chicken meat and were calculated as follows [11, 12]:

$$
\begin{gathered}
\mathrm{S} / \mathrm{P}=(\mathrm{C} 14: 0+\mathrm{C} 16: 0+\mathrm{C} 18: 0) /(\mathrm{MUFA}+\mathrm{PUFA}) \\
\mathrm{AI}=(\mathrm{C} 12: 0+4 \times \mathrm{C} 14: 0+\mathrm{C} 16: 0) /(\mathrm{MUFA}+\mathrm{PUFA}) \\
\mathrm{TI}=(\mathrm{C} 14: 0+\mathrm{C} 16: 0+\mathrm{C} 18: 0) /[(\mathrm{MUFA}+\omega-6 \mathrm{PUFA}) / 2+3 \times \omega-3 \mathrm{PUFA}+\omega-3: \omega-6]
\end{gathered}
$$

196 The other health indices of chicken meat viz. Desirable fatty acids (DFA), Hypercholesterolemic 197 fatty acids (HFA), and ratio of hypocholesterolemic fatty acids to hypercholesterolemic fatty acids $(\mathrm{h} / \mathrm{H})$ were calculated as follows [28]:

$$
\begin{aligned}
& \text { DFA }=\text { UFA }+ \text { C18: } 0 \\
& \text { HFA }=\text { C12: } 0+\text { C14: } 0+\text { C16:0 }) \\
& \text { h/H }=(\text { C18: } 1+\text { PUFA }) /(C 14: 0+\text { C16:0 })
\end{aligned}
$$

\section{Serum lipid chemistry and health indices}

The serum total cholesterol, HDL cholesterol, triglyceride, and glucose estimation was done by using the Cogent, SPAN diagnostics kits following the instructions of the manufacturer. The serum thiobarbituric acid reactive substances (TBARS) value measures the extent of lipid oxidation in the body and it was expressed in terms of $\mu \mathrm{M}$ malondialdehyde (MDA) [29]. The antioxidant defence system of the body contains various antioxidant enzymes such as superoxide dismutase (SOD), catalase (CAT), glutathione peroxidase (GSH-Px), and glutathione reductase 
209 (GR). These enzymes were assayed by using the Cayman diagnostic kits [30]. All the samples

210 and standards were measured in duplicate.

211 The atherogenic indices of serum were calculated by the method described by Frolich et al. [31] 212 as follows:

213 Cardiac Risk Ratio (CRR) $=$ Total cholesterol/HDL cholesterol

214 Atherogenic Coefficient $(\mathrm{AC})=($ Total cholesterol - HDL cholesterol $) /$ HDL cholesterol

215 Atherogenic Index of Plasma (AIP) $=($ Total cholesterol - HDL cholesterol $) / H D L$ cholesterol

\section{Statistical analysis}

217 For the analysis of data pertaining to feed intake, FCR, PEF, PER, and EER, each replicate was

218 taken as an experimental unit, whereas, for all other parameters the sampled bird was taken as an experimental unit. All data were tested for normality and homogeneity of variances with the Shapiro-Wilk test and Levene's test respectively prior to analyses. The data were analysed by one way ANOVA using the General Linear Model procedure (IBM SPSS software-20). The significant mean differences were separated by Tukey post-hoc analysis with significance level defined at $\mathrm{P}<0.05$. Further, to validate the effects of $\mathrm{Cr}$ supplementation the data were also subjected to polynomial orthogonal contrast.

\section{Results}

\section{Growth performance}

227 The BWG of birds during $0-3$ weeks of age was lower $(\mathrm{P}=0.009)$ in $\mathrm{T} 2$ group followed by statistically different T3 and T4 groups, whereas higher BWG was observed in T5 and T1 which did not differ significantly from each other (Table 2). Similarly, the FCR during 0-3 weeks of

230 age was higher $(\mathrm{P}=0.006)$ in $\mathrm{T} 2$ group compared to other treatments groups which did not differ significantly from each other. The feed intake and 4-6 week and 0-6 week BWG and FCR of birds were not affected by dietary treatments. The mortality pattern of birds also showed no 
233 significant dietary effects (data not shown, only 2 birds died from T3 and 1 bird each from T1,

234 T2, \& T4 treatment groups during whole experimental period).

\section{Growth efficiency parameters}

236 In line with the results of growth performance of birds given above, during 0-3 weeks of age

237 lower PEF $(\mathrm{P}=0.008)$, PER $(\mathrm{P}=0.010)$, and EER $(\mathrm{P}=0.007)$ of birds were observed in group

238 T2 compared to other treatment groups which did not differ significantly from each other (Table

239 3). However, PEF, PER, and EER during 4-6 weeks and 0-6 weeks of age were not affected by

240 dietary treatments.

\section{Carcass characteristics and cost economics}

242 The carcass characteristics revealed no significant dietary treatment effects except the abdominal

243 fat (Table 4). Lower ( $\mathrm{P}=0.019)$ abdominal fat of birds was observed in $\mathrm{T} 5$ group followed by 244 statistically similar T4 group. Higher abdominal fat was observed in T1 group followed by 245 statistically different T2 and T3 groups which were not significantly different from T4 group. 246 With respect to control diet (T1) all other treatment groups revealed an increase in cost per $\mathrm{kg}$ 247 live weight $(\mathrm{P}=0.021)$ and per $\mathrm{kg}$ meat yield $(\mathrm{P}=0.018)$ with higher increase in group $\mathrm{T} 2$ and 248 less increase in group T5. However, group T3, and T4 were statistically similar to both T2 and 249 T5.

\section{Sensory quality of chicken meat}

251 None of the sensory quality attributes of either cooked or raw chicken meat revealed significant 252 dietary effects (Table 5).

\section{Fatty acid profile of chicken meat}

254 The fatty acid profiles of broiler chicken thigh and breast meat are given in Table $6 \& 7$, respectively. Higher percentages of C16:0, C18:0, SFA; and lower percentages of C18:1, C18:2 
$\omega-3$ PUFA, and $\omega-6$ PUFA were observed in group T1 compared to other treatment groups which

258 did not differ significantly from each other.

259 Fatty acid metabolism of chicken meat

260 The fatty acid metabolism indices of thigh and breast meat revealed that DI (18), DI (16), total

261 DI, and $\Delta^{5}+\Delta^{6}$ - desaturase index were lower $(\mathrm{P}<0.05)$ and elongase and thioesterase indices were higher $(\mathrm{P}<0.05)$ in control group $\mathrm{T} 1$ compared to other treatments groups which did not differ significantly from each other (Table 8 ).

\section{Health indices of broiler chicken meat}

The health indices of chicken meat under the influence of FSM and Cr feeding revealed lower $(\mathrm{P}<0.01)$ PUFA:SFA ratio, MUFA:SFA ratio, UFA:SFA ratio, the DFA content, and $\mathrm{h} / \mathrm{H}$ ratio in control group T1 compared to other treatment groups which did not differ significantly from each other (Table 9). However, higher $\omega-6: \omega-3$ fatty acid ratio, saturation index, atherogenic index (AI), thrombogenic index (TI), and hypercholesterolemic fatty acids (HFA) were observed in control group T1 compared to other treatment groups which were statistically similar to each other.

\section{Serum lipid chemistry and health indices}

273 The serum lipid chemistry, antioxidant enzyme activities, and associated health indices are given

274 in Table 10. No significant dietary effects were observed on the serum glucose concentration.

275 However, higher serum triglyceride $(\mathrm{P}=0.011)$ and total cholesterol $(\mathrm{P}=0.021)$ concentrations were observed in control group T1 compared to group T2 and linear decrease $(\mathrm{P}=0.021 \& 0.016$, respectively) was observed in groups supplemented with increasing $\mathrm{Cr}$ levels. Serum HDL

278 cholesterol was lower $(\mathrm{P}=0.011)$ in control group $\mathrm{T} 1$ compared to group $\mathrm{T} 2$ and it increased 279 linearly $(\mathrm{P}=0.014)$ in treatment groups supplemented with increasing $\mathrm{Cr}$ levels. Serum 280 antioxidant enzyme activities and MDA concentrations have shown a unique trend. Higher activities of SOD $(\mathrm{P}=0.007)$, CAT $(\mathrm{P}=0.001)$, GSH-Px $(\mathrm{P}=0.002)$, GR $(\mathrm{P}<0.001)$, and 
282 TBARS value $(\mathrm{P}=0.009)$ were observed in group $\mathrm{T} 2$ compared to control group $\mathrm{T} 1$ and these serum parameters decreased linearly $(\mathrm{P}=0.004,<0.001,0.001,<0.001, \& 0.006$, respectively $)$ with increasing $\mathrm{Cr}$ levels in the diets, such that group T5 depicted lower values compared to control group T1. Higher values of health indices such as CRR $(\mathrm{P}=0.033), \mathrm{AC}(\mathrm{P} 0.022)$, and AIP $(\mathrm{P}=0.007)$ were observed in control group T1 compared group T2 and linear reduction of CRR $(\mathrm{P}<0.001), \mathrm{AC}(\mathrm{P}=0.003)$, and AIP $(\mathrm{P}=0.012)$ was observed with increasing Cr levels in the chicken diets.

\section{Discussion}

290 A number of researchers consistently reported poor growth performance of birds with increasing 291 levels of flaxseed in the broiler chicken diets [32, 33, 34] due to poor energy availability, 292 presence of anti-nutritional factors, low digestibility of flaxseed and high viscosity of jejunal 293 digesta [35]. However, results of the present were peculiar in that negative effects of $100 \mathrm{~g}$ FSM on BWG and FCR of birds were observed only up to 3 weeks of age, indicating the age dependence of negative effects of FSM feeding in broiler chicken. Similar age dependence of negative effects of FSM feeding was observed on the PEF, PER, and EEF of birds only up to 3 weeks of age. Poor growth performance and efficiency of birds fed FSM indicates their poor efficiency of feed, protein, and energy utilization [36]. Even some old studies maintain that

299 feeding ground flaxseed beyond 7.5\% level in broiler chicken reduced the growth and conversion efficiency, explaining the reduction in PER and net protein ratio, which could be due to lower nitrogen and amino acid retention because of the presence of mucilage [16, 17]. However, in

302 present study the negative effects of FSM feeding during starter phase seem to be overcome by

303 Cr supplementation. But Cr levels did not differ significantly from each other except that the 304 BWG of birds supplemented with only $1.5 \mathrm{mg} \mathrm{Cr} / \mathrm{kg}$ diet could match the BWG of control diet fed birds. In earlier studies Cr supplementation in broiler chicken improved BWG and efficiency 
306 of feed utilization [1, 37]. Contrary to this no significant effects of $\mathrm{Cr}$ supplementation were 307 observed in other studies [38, 39]. The mortality of birds, well within permissible limits, was 308 found to have no impact of different dietary treatments in the present study. On the similar lines 309 in earlier studies flaxseed feeding [32] and $\mathrm{Cr}$ supplementation [38] were found to have no 310 significant effect on broiler chicken mortality.

311 The decline of abdominal fat in broiler chicken fed FSM can be attributed to enhanced 312 UFA content in meat at the cost of SFA and former undergo rapid oxidation compared to their 313 saturated counter parts. The FSM also exerts its effect by increasing gut viscosity which hinders 314 the micelle formation and thus diminish lipid uptake, thereby reducing its deposition in the body 315 [8]. Further, the increased leptin protein levels were observed in rabbits fed diet supplemented 316 with $100 \mathrm{~g}$ flaxseed [40] which can also be responsible for reduction of abdominal fat deposition 317 in animals. On the other hand linear reduction in abdominal fat was observed with increasing $\mathrm{Cr}$ 318 levels in the present study. This can be attributed to the fact that $\mathrm{Cr}$ supplementation improves 319 insulin sensitivity of tissues which causes enhanced deposition of dietary protein and 320 carbohydrate in muscle cells compared to fat [41]. In line with the results of present study carcass 321 characteristics in broiler chicken were not affected by $100 \mathrm{~g}$ flaxseed feeding [32, 33, 42] or $\mathrm{Cr}$ supplementation $[39,43]$. The feed cost per $\mathrm{kg}$ live weight and per $\mathrm{kg}$ meat yield increased by $10.50 \%$ and $9.65 \%$, respectively, due to the inclusion of $100 \mathrm{~g}$ FSM in chicken diets. However,

324 Cr supplementation could linearly decrease this rise of feed cost by just $2.86 \%$ and $2.97 \%$, 325 respectively, by improving the feed efficiency of birds. This increase of feed cost can be justified based on the fact that FSM results in $\omega-3$ PUFA enrichment of meat whose consumption has well documented health benefits in humans. Previous studies have also reported increase in feed cost by inclusion of flaxseed in broiler chicken ration [16, 44]. However, no such studies are available which show the effect of $\mathrm{Cr}$ supplementation on feed cost of broiler chicken. 
331 of Mridula et al. [33, 36] who observed that organoleptic properties of meat did not show any significant effect of FSM inclusion in the diet of broiler chicken. Further, sensory quality of breast or thigh meat [42] and sensory values (aroma, flavour, aftertaste, overall acceptability) of

334 breast and thigh meat patties made for chicken fed did not exhibit any significant effect of

335 flaxseed feeding. On the other hand, thermally treated breast and leg muscles did not show any differences in organoleptic characteristics as a result of chromium supplementation in broiler diet [1]. Further, not enough literature is available pertaining to the impact of chromium on the sensory evaluation of broiler meat. chicken diets has been carried out to alter the fatty acid composition of chicken meat in earlier

341 studies $[8,11,12,14,41]$. Significant improvement in fatty acid profile of chicken meat was observed in present study by inclusion of $100 \mathrm{~g}$ FSM/kg diet of broiler chicken. Flaxseed is the richest terrestrial source of $\omega-3$ fatty acids (particularly ALA), which undergo faster absorption in the gut of birds without any significant bio-hydrogenation and can be the reason for higher UFA content in chicken meat at the expense of SFA content $[8,14,41]$. Increase in long chain PUFA such as EPA, DPA, and DHA content of chicken meat could be because of enhancement of de novo synthesis of long chain PUFA from LA and ALA supplied by dietary FSM [45]. On similar lines increased $\omega-3$ fatty acids, particularly ALA, EPA, DPA, and DHA content in broiler chicken meat was observed by inclusion of flaxseed in broiler chicken ration $[8,11,12,14,34$,

$35041]$. Broiler chicken do have the ability to convert some dietary ALA to EPA, DPA, and DHA $351[11,12]$ which indicates that EPA and DHA can be made available from chicken meat conveniently other than the conventional marine sources. There are no such reports available on chicken showing the effects of $\mathrm{Cr}$ on fatty acid profile of chicken meat. However, similar to the 
results of present study no significant changes in tissue fatty acid profiles of swine [46], and cattle [47] were observed due to dietary Cr supplementation.

The changes in the lipid composition of broiler chicken meat observed in this study due

to FSM feeding could be the results of alteration in lipid metabolism and the consequent lipid deposition in chicken tissues [48]. Feeding of $100 \mathrm{~g}$ FSM increased $\Delta^{9}$-DI (16), $\Delta^{9}$-DI (18), total $\Delta^{9}$-DI, and $\Delta^{5}+\Delta^{6}$ desaturase activities in broiler chicken meat and decreased elongase and thioesterase indices. Age and diet of broiler chicken are two important determinants of $\Delta^{9}$ desaturase activity [49]. In the present study it can be FSM induced increase in $\Delta^{9}$ desaturase activity because the birds used were of same age group and the same has been reported by Kumar et al. [11]. The $\Delta^{9}$-desaturase enzymes catalyze the conversion of endogenous and dietary specific medium- and long-chain SFA (palmitic, C16:0 and stearic acid, C18:0) to their corresponding MUFA (palmitoleic, C16:1 and oleic acid, C18:1) [12, 50]. The decreased elongase and thioesterase indices indicate lower conversion of myristic acid (C14:0) to palmitic acid (C16:0) and further to stearic acid (C18:0) which reflects the trend of steric acid in the fatty acid profile of chicken meat. On the other hand, animals do not have the ability to synthesize essential fatty acids (EFA) such as LA and ALA from acetyl-CoA, but they can convert them to more unsaturated long chain FA in liver when supplied in diet. This process is catalysed by $\Delta^{5}$ and $\Delta^{6}$ desaturases which are rate limiting enzymes in this process of conversion. In present study $100 \mathrm{~g}$ FSM feeding induced higher $\Delta^{5}+\Delta^{6}$ desaturase index which reflects the trend of EPA, DPA, and DHA content of the chicken meat and this relationship between long chain PUFA and $\Delta^{5}+\Delta^{6}$ desaturase activities in chicken tissues has also been established in earlier studies [11, 27]. However, $\mathrm{Cr}$ supplementation did not show any significant effect on the fatty acid metabolism indices which corroborate the trend of fatty acid profile of chicken meat observed in this study. Notwithstanding the knowledge of authors, there is no literature available pertaining to the effects of $\mathrm{Cr}$ supplementation on fatty acid metabolism in broiler chicken meat. 
380 evaluation of food quality [51]. The greater the degree of UFA content, particularly $\omega-3$ fatty

381 acids, greater are the health benefits of food items. The ratio of $\omega-6$ to $\omega-3$ is an important index

382 of meat quality of animals/birds. The metabolism of EFA, LA ( $\omega-6$ fatty acid) and ALA ( $\omega-3$

383 fatty acid), to their corresponding long chain PUFAs share common pathways and pool of

384 metabolic enzymes [52]. Because of the competition between these two distinct families of EFAs

385 for the same set of enzymes an excess of substrate of one family hinders the metabolism of other,

386 reduces its incorporation into the tissues, and hence, the consequent biological effects [53]. In

387 this regard, flaxseed has been reported containing $32-45 \%$ oil, of which $51-55 \%$ is ALA and

$38815-18 \%$ is LA [54] and presenting an $\omega-6: \omega-3$ ratio of $0.3: 1$ which makes it most suitable for

$389 \omega-3$ enrichment of chicken meat. Thus, the present study provides intuitions that feeding of FSM

390 in broiler chicken offers a unique strategy of increasing the long chain $\omega-3$ PUFAs such as EPA,

391 DPA, and DHA in chicken meat at the expense of $\omega-6$ PUFAs. As a result of enhanced

392 unsaturation of chicken meat due to dietary FSM PUFA:SFA ratio, MUFA:SFA ratio, UFA:SFA

393 ratio, the DFA content, and $\mathrm{h} / \mathrm{H}$ ratio of chicken meat increased, whereas, $\omega-6: \omega-3$ fatty acid

394 ratio, saturation index, atherogenic index (AI), thrombogenic index (TI), and

395 hypercholesterolemic fatty acids (HFA) decreased. The $\omega-6$ : $\omega-3$ fatty acid ratio improved from

$396 \quad 5.4: 1$ to $3.4: 1$ in thigh meat and from $7.7: 1$ to $3.3: 1$ in breast meat which indicates differential

397 deposition rate of different fatty acids in breast and thigh meat. Similarly, in recent studies on

398 broiler chicken dietary flaxseed improved tissue $\omega-6: \omega-3$ fatty acid ratio and PUFA:SFA ratio

$399[11,12,55]$. Lower AI and TI, observed in present study, have been reported to exert protective

400 action against coronary heart diseases [55]. Furthermore, $100 \mathrm{~g}$ flaxseed feeding elevated the

401 leptin protein levels in rabbits, which has a strong positive correlation with adipose ALA levels

402 [40] and hence inversely correlated with the risk of cardiovascular diseases [56]. The diets rich 
403 in saturated fatty acids, such as lauric acid (C12:0), myristic acid (C14:0), and palmitic acid 404 (C16:0), have shown higher correlation with increased risk of atherosclerosis, obesity, and 405 coronary heart diseases $[11,57]$. But the higher $\Delta^{9}$ desaturation activity observed in the current 406 study is supposed to counter these unwanted outcomes to a certain extent by converting palmitic 407 acid to palmitoleic acid. However, Cr supplementation in present did not affect the health indices 408 of broiler chicken meat because of nonsignificant effect on the metabolism and composition of 409 fatty acids of chicken tissues. Notwithstanding the knowledge of authors, no literature 410 deciphering the influence of $\mathrm{Cr}$ supplementation on the health indices of broiler 411 chicken/animal/humans is available.

412 In present study feeding of $100 \mathrm{~g}$ FSM resulted in lower serum cholesterol, triglyceride, 413 CRR, AC, and AIP; and linear decrease was observed in all these parameters due to $\mathrm{Cr}$ 414 supplementation. Flaxseed interferes in bile acid metabolism by inhibiting the re-uptake of bile 415 acids, which diverts cholesterol towards the hepatic synthesis of bile acids and thus reduces its 416 serum concentration in broiler chicken/humans $[14,58]$. The decrease in serum triglyceride 417 levels may be because of increased tissue $\omega-3$ fatty acid content due to FSM feeding. In various 418 animal models like rats, mice, and rabbit flaxseed feeding exert hypocholesterolemic effects, 419 generally due to the greater fecal excretion of lipids [59]. In line with the results of present study 420 decline of serum cholesterol and triglyceride levels occurred as a result of flaxseed feeding in 421 broiler chicken [22, 35] and humans [58]. The effect of flaxseed feeding on serum HDL 422 cholesterol have resulted in various conflicting reports. Similar to the present results, flaxseed 423 feeding increased serum HDL cholesterol [58], whereas, no significant changes in serum HDL 424 cholesterol levels have also been reported [60]. On the other hand, $\mathrm{Cr}$ seems to exerts 425 hypocholesterolemic and hypolipidemic effects by activating 5-AMP-activated kinase which 426 negatively regulates sterol regulatory element binding protein-1 (SREBP-1). This SREBP-1 is 427 required for synthesis and uptake of cholesterol and triglycerides [20]. The Cr supplementation 
reduced the muscle cholesterol by $40 \%$ and serum cholesterol by $30 \%$ in broiler chicken supplemented by organic $\mathrm{Cr}$ [3]. The lower plasma concentration of HDL-C is considered as a major risk factor for the development of cardiovascular diseases [60]. Researchers have shown

431 that an increase in plasma HDL-C concentration reduces cardiovascular risk [61] which supports 432 the decline of CRR, AC, and AIP in the present study. The serum lipid profile has a direct 433 relationship with the risk factors of cardiovascular diseases [56] and improved lipid profile 434 results in lower atherogenic indices which provide protection against coronary heart diseases 435 [55]. PUFA decreases cholesterol content more strongly than MUFA; and oleic acid and linolenic 436 acid exert antiatherogenic properties [57]. Similar to the present study, a significant improvement 437 in atherogenic indices of humans [58] and chicken [11] were observed due to dietary flaxseed.

438 The increase in serum antioxidant enzyme activities and TBARS value of broiler chicken in 439 present study has been reported in recent studies [22, 35]. This can be attributed to increased 440 lipid unsaturation in chicken meat, supported by increased TBARS values, which induces the 441 enhanced antioxidant enzyme activities [34, 61]. Linear decrease in antioxidant enzyme activities 442 and TBARS value were observed with increasing Cr levels in diet of chicken. Cr serves as an 443 antioxidant which provides protection against lipid peroxidation [18] and hence reverses the 444 antioxidant enzyme induction property of FSM. Cr supplementation in cows significantly lower 445 plasma SOD with no effect on GPx or GR [62] and reduced lipid peroxidation due to $\mathrm{Cr}$ 446 supplementation with no significant effect on serum antioxidant enzymes was observed in birds 447 [39].

\section{Conclusion}

449 The study concludes that $100 \mathrm{~g}$ FSM feeding exerts negative effects on the growth performance 450 during starter phase only (0-3 weeks) and overall growth efficiency in broiler chicken, whereas, 451 Cr supplementation reverses these negative effects. The $100 \mathrm{~g}$ FSM feeding reduces abdominal 
452 fat in broiler chicken and $\mathrm{Cr}$ supplementation linearly decreases it with minimum value at 1.5

$453 \mathrm{mg} \mathrm{Cr} / \mathrm{kg}$ diet. The $100 \mathrm{~g}$ FSM feeding favourably alters the lipid metabolism to improve the

454 meat lipid profile and health indices and no such effects are exerted by $\mathrm{Cr}$ supplementation. The $455100 \mathrm{~g}$ FSM feeding improves serum lipid profile and atherogenic indices and linear improvement 456 occurs in these parameters with increasing Cr levels up to $1.5 \mathrm{mg} / \mathrm{kg}$ chicken diet. And, $100 \mathrm{~g}$

457 FSM feeding decrease the serum antioxidant status which is improved by $1.5 \mathrm{mg} \mathrm{Cr} / \mathrm{kg}$ diet in 458 broiler chicken.

\section{Abbreviations}

460 Cr: Chromium; PUFA: Polyunsaturated Fatty Acids; ALA: Alpha-linolenic acid; LA: Linoleic 461 acid; EPA: Eicosapentaenoic acid; DHA: Docosahexaenoic acid; UFA: Unsaturated fatty acids; 462 SFA: Saturated fatty acids; SOD: Superoxide dismutase; GSH-Px: Glutathione peroxidase; GR: 463 Glutathione reductase; FSM: Flaxseed meal; BWG: Body weight gain; FCR: Feed conversion 464 ratio; PEF: Production efficiency factor; PER: Protein efficiency ratio; EER: Energy efficiency 465 ratio; FAME: Fatty acid methyl esters; GC: Gas chromatograph; DI: Desaturase index; DFA: 466 Desirable fatty acids; HFA: Hypercholesterolemic fatty acids; TBARS: Thiobarbituric acid 467 reactive substances; CRR: Cardiac risk ratio; AC: Atherogenic coefficient; AIP: Atherogenic 468 index of plasma

\section{Acknowledgements}

470 There is none to acknowledge

\section{Authors' contributions}

472 NAM, AB, DS, CD: Conceptualization, Methodology, Data collection, Writing

473 PKT, JB, KD: Methodology, Writing-reviewing and Editing

474 JB, KD, NAM: Data collection, Writing

475 AB, PKT, DS, CD: Supervision, Editing 
476 PKT, ABM, NAM: Conceptualization, Methodology, Data analysis

477 Funding

478 This research did not receive any funding from any agency

479 Availability of data and materials

480 Data will be available from the corresponding author upon reasonable request

481 Ethical approval and consent to participate

482 The experimental procedures carried out in the study were approved by the Institutional Animal

483 Ethics Committee (IAEC) following the guidelines of "Committee for the Purpose of Control 484 and Supervision of Experiments on Animals (CPCSEA) 2012" established under the 'Prevention 485 of Cruelty to Animals Act 1960' of Indian Penal Code (Approval number 604/09/bc/CPCSEA).

\section{Consent for publication}

$487 \quad$ Not applicable

\section{Competing of interest}

489 The authors declare that they have no competing interest arising out of this manuscript

$490 \quad$ References

491 1. Kroliczewska B, Zawadkzki W, Skiba T, Mista D. Effects of chromium supplementation on 492 chicken growth and carcass characteristics. Acta Vet Brno. 2005;74:543-549.

2. Amata A. Chromium in livestock nutrition: A review. Glob Adv Res J Agri Sci. 494

3. Debski B, Zalewski W, Gralak MA, Kosla T. Chromium-yeast supplementation of chicken broilers in an industrial farming system. J Trace Elem Med Biol. 2004;18:47-51.

4. Sahin K, Sahin N, Kucuk O. Effects of chromium and ascorbic acid supplementation on growth, carcass traits, serum metabolites, and antioxidant status of broiler chickens reared at a high ambient temperature $\left(32^{\circ} \mathrm{C}\right)$. Nutr Res. 2003;23:225-238. 
5. Hossain SM. Organic Chromium in Poultry: Metabolic Responses, Effects on Broiler Carcass Composition, Nutrient Composition of Eggs. 2007. https://en.engormix.com/poultryindustry/articles/organic-chromium-in-poultry-t33943.htm Accessed online 19/05/20,

6. Toghyani M, Shivazad M, Gheisari AA, Zarkesh SH. Performance, carcass traits and 3:35 PM.

7. Matis G, Lengyel P, Kulcsar A, Kulcsarne Petrilla J, Neogrady ZS. Special characteristics of carbohydrate metabolism and insulin homeostasis in chicken. Literature review. Magy hematological parameters of heat stressed broiler chicks in response to dietary levels of chromium picolinate. Int J Poultry Sci. 2006;5(1):65-69.

8. Mir NA, Tyagi PK, Biswas AK, Tyagi PK, Mandal AB, Kumar F, et al. Inclusion of flaxseed, broken rice, and distillers dried grains with solubles (DDGS) in broiler chicken ration alters the fatty acid profile, oxidative stability, and other functional properties of meat.

9. Siegel G, Ermilov E. Omega-3 fatty acids: Benefits for cardio-cerebro-vascular diseases. Atherosclerosis 2012;225:291-295.

10. del Gobbo LC. Omega-3 polyunsaturated fatty acid biomarkers and coronary heart disease: pooling project of 19 cohort studies. JAMA Int Med. 2016;176:1155-1166. for different durations on the lipid deposition and meat quality in broiler chickens. J Am Oil Chemists' Soc. 2019;96:261-271. 
521

522

523

524

525

526

527

528

529

530

531

532

533

534

535

536

537

538

539

540

541

12. Kumar F, Tyagi PK, Mir NA, Dev K, Begum J, Biswas A, et al. Dietary flaxseed and turmeric is a novel strategy to enrich chicken meat with long chain $\omega-3$ polyunsaturated fatty acids with better oxidative stability and functional properties. Food Chem. 2020;305. doi.org/10.1016/j.foodchem.2019.125458.

13. Kouba M, Mourot J. A review of nutritional effects on fat composition of animal products with special emphasis on n-3 polyunsaturated fatty acids. Biochimie 2011;93:13-17.

14. Mir NA, Tyagi PK, Biswas AK, Tyagi PK, Mandal AB, Wani MA, et al. Performance and meat quality of broiler chicken fed a ration containing flaxseed meal and higher dietary lysine levels. J Agric Sci. 2018;156(2):291-299.

15. Shen Y, Feng D, Fan MZ, Chavez ER. Performance, carcass cut-up and fatty acids deposition in broilers fed different levels of pellet-processed flaxseed. J Sci Food Agric. 2005;85:2005-2014.

16. Zuidhof MJ, Betti M, Korver R, Hernandez FIL, Schneider BL, Carney FL, et al. Omega-3enriched broiler meat: 1. Optimization of a production system. Poult Sci. 2009;88:11081120.

17. Azcona JO, Schang MJ, Garcia PT, Gallinger C, Ayerza Jr R, Coates W. Omega-3 enriched broiler meat: The influence of dietary $\alpha$-linolenic- $\omega-3$ fatty acid sources on growth, performance and meat fatty acid composition. Can J Anim Sci. 2008;88:257-269.

18. Anderson RA. Exercise effects on trace element metabolism. In: Rousssel AM, Anderson RA, Favier AE, editors. Trace element in man and animal. New York USA: Kluwer Academic/Plenum Publishers; 2000. pp. 393-397. 
19. Hoeck VV, Sonawane M, Sanchez ALG, Dosselaer IV, Buyens C, Morisset D. Chromium propionate improves performance and carcass traits in broilers Anim Nutr. 2020. https://doi.org/10.1016/j.aninu.2020.03.005

20. Rajalekshmi M, Gnanasekar R, Chirakkal H. Role of chromium in livestock nutrition: A review. 2008. https://en.engormix.com/dairy-cattle/articles/chromium-in-livestocknutrition-t34328.htm Accessed online 19/05/202, 12:46 PM.

21. Ohh SJ, Lee JY. Dietary chromium-methionine chelate supplementation and animal performance. Asian-Aust J Anim Sci. 2005;18:898-907.

22. Mir NA, Tyagi PK, Biswas AK, Tyagi PK, Mandal AB, Hazarika R, et al. Response of broiler chicken in terms of growth and efficiency, carcass characteristics, sensory quality of meat and serum biochemical profile to different lysine levels in flaxseed based diet. Anim Nutr Feed Technol. 2018;18:141-152.

23. Keeton JT. Effect of fat or sodium chloride or phosphate level on the chemical sensory properties of pork patties. J Food Sci. 1983;48:878-881.

24. O’Fallon JV, Busboom JR, Nelson ML, Gaskins CT. A direct method for fatty acid methyl ester (FAME) synthesis: Application to wet meat tissues, oils and feedstuffs. J Anim Sci. 2007;85:1511-1521.

25. Okada T, Furuhashi N, Kuromori Y, Miyashita M, Iwata F, Harada K. Plasma palmitoleic acid content and obesity in children. Am J Clin Nutr. 2005;82:747-750.

26. Zhang S, Knight TJ, Stalder KJ, Goodwin RN, Lonergan SM, Beitz DC. Effects of breed, sex, and halothane genotype on fatty acid composition of pork longissimus muscle. $\mathrm{J}$ Anim Sci. 2007;85:583-591. 
27. Sirri F, Castellini C, Roncarati A, Meluzzi A. Effect of feeding and genotype on lipid profile of organic chicken meat. Euro J Lipid Sci Technol. 2010;112:994-1002.

566

567

568

569

570

571

572

573

574

575

576

577

578

579

580

581

582

583

584

585

28. Pilarczyk R, Woojcik J, Sablik P, Czerniak P. Fatty acid profile and health lipid indices in the raw milk of Simmental and Holstein-Friesian cows from an organic farm. S Afr J Anim Sci. 2015;45(1):30-38.

29. Yagi K. Simple assay for the levels of total lipid peroxides in serum or plasma. Meth Mol Biol. 1998;108:101-106.

30. Wheeler CR, Salzman JA, Elsayed NM, Omaye ST, Korte DW Jr. Automated assays for superoxide dismutase, catalase, glutathione peroxide and glutathione reductase activity. Anal Biochem. 1990;184:193-199.

31. Frohlich J, Dobiasova M. Fractional esterification rate of cholesterol and ratio of triglycerides to HDL-Cholesterol are powerful predictors of positive findings on coronary angiography. Clin Chem. 2003;49:1873-1880.

32. Pekel AY, Patterson PH, Hulet RM, Acar N, Cravener TL, Dowler DB, et al. Dietary camelina meal versus flaxseed with and without supplemental copper for broiler chickens: live performance and processing yield. Poult Sci. 2009;88:2392-2398.

33. Mridula D, Kaur D, Nagra SS, Barnwal P, Gurumayum S, Singh KK. Growth performance, carcass traits and meat quality in broilers, fed flaxseed meal. Asian Austral J Anim Sci. 2011;24:1729-1735.

34. Anjum FM, Haider MF, Khan MI, Sohaib M, Arshad MS. Impact of extruded flaxseed meal supplemented diet on growth performance, oxidative stability and quality of broiler meat and meat products. Lipids Health Dis. 2013;12:13-24. 
35. Mir NA, Tyagi PK, Biswas AK, Tyagi PK, Mandal AB, Kumar F, et al. Effect of feeding broken rice and distillers dried grains with solubles (DDGS) in flaxseed based diet on growth performance \& efficiency, carcass characteristics, sensory evaluation of meat and serum biochemistry of broiler chicken. Turk J Vet Anim Sci. 2017;41:583589.

36. Mridula D, Kaur D, Nagra SS, Barnwal P, Gurumayum S, Singh KK. Growth performance and quality characteristics of flaxseed-fed broiler chicks. J Appl Anim Res. 2015;43:345351.

37. Kheiri F, Toghyani M. Effect of different levels of inorganic chromium on performance and immunity of broiler chicks. J Anim Vet Adv. 2009;9:1819-1823.

38. Jackson AR, Powell S, Johnston S, Shelton JL, Bidner TD, Valdez FR, et al. The effect of chromium propionate on growth performance and carcass traits in broilers. J Appl Poult Res. 2008;17:476-4814.

39. Ramarao SV, Panda MV, Poonam LN, Krishna Murthy G, Shyam Sunder O. Effect of dietary supplementation of organic chromium on performance carcass traits, oxidative parameters and immune response in commercial broiler chickens. Biol Trace Elem Res. 2012;147:135-141.

40. McCullough RS, Edel AL, Bassett CMC, LaValle RK, Dibrov E, Blackwood DP, et al. The alpha linolenic acid content of flaxseed is associated with an induction of adipose leptin expression. Lipids 2011;46:1043-1052.

41. Mir NA, Tyagi PK, Biswas AK, Tyagi PK, Mandal AB, Sheikh SA, et al. Impact of feeding chromium supplemented flaxseed based diet on fatty acid profile, oxidative stability and 
608

609

610

611

612

613

614

615

616

617

618

619

620

621

622

623

624

625

626

627

628

other functional properties of broiler chicken meat. J Food Sci Technol. 2017;54:38993907.

42. Gonzalez-esquerra R, Leeson S. Effects of menhaden oil and flaxseed in broiler diets on sensory quality and lipid composition of poultry meat. Br Poult Sci. 2000;41:481-488.

43. Anandhi M, Mathivanan R, Viswanathan K, Mohan B. Dietary inclusion of organic chromium on production and carcass characteristics of Broilers. Int J Poult Sci. 2006;5(9):880-884.

44. Cerina S, Krastina V, Vitina I. Production and expenses of enriched composition broiler chicken meat in Latvia. Agro Res. 2011;9:383-388.

45. Smink W, Gerrits WJ, Hovenier R, Geelen MJ. Effect of dietary fat sources on fatty acid deposition and lipid metabolism in broiler chickens. Poult Sci. 2010;89:2432-2440.

46. Jackson AR, Powell S, Johnston S, Shelton JL, Bidner TD, Valdez FR, et al. The effect of chromium as chromium propionate on growth performance, carcass traits, meat quality, and the fatty acid profile of fat from pigs fed no supplemented dietary fat, choice white grease, or tallow. J Anim Sci. 2009;87:4032-4041.

47. Nejad JG, Lee BH, Kim BW, Ohh SJ, Sung K Il. Effects of chromium methionine supplementation on blood metabolites and fatty acid profile of beef during late fattening period in holstein steers. Asian Austral J Anim Sci. 2016;29:378-383.

48. Dal Bosco A, Mugnai C, Ruggeri S, Mattioli S, Castellini C. Fatty acid composition of meat and estimated indices of lipid metabolism in different poultry genotypes reared under organic system. Poult Sci. 2012;91:2039-2045. 
49. Poureslami R, Turchini GM, Raes K, Huyghebaert G, De Smet S. Effect of diet, sex and age on fatty acid metabolism in broiler chickens: SFA and MUFA. Br J Nutr. 2010;104:204213.

50. Reh WA, Maga EA, Collette NMB, Moyer A, Conrad-Brink JS, Taylor SJ, et al. Using a stearoyl- CoA desaturase transgene to alter milk fatty acid composition. J Dairy Sci. 2004;87:3510-3514.

51. Legrand P, Hermier D. Hepatic delta 9 desaturation and plasma VLDL level in genetically lean and fat chickens. Int J Obes Relat Metab Disord. 1992;16:289-294.

52. Poudyal H, Panchal SK, Diwan V, Brown L. Omega-3 fatty acids and metabolic syndrome: effects and emerging mechanisms of action. Prog Lipid Res. 2011;50:372-387.

53. Burdge GC, Calder PC. Conversion of $\alpha$-linolenic acid to longer-chain polyunsaturated fatty acids in human adults. Reprod Nutr Dev. 2005;45:581-597.

54. Prasad K. Flaxseed and cardiovascular health. J Cardiovas Pharmacol. 2009;54:369-377.

55. Usoro CA, Adikwuru CC, Usoro IN, Nsonwu AC. Lipid profile of postmenopausal women in Calabar, Nigeria. Pak J Nutr. 2006;5:79-82.

56. Goyal A, Sharma V, Upadhyay N, Gill S, Sihag M. Flax and flaxseed oil: an ancient medicine \& modern functional food. J Food Sci Technol. 2014;51:1633-1653.

57. Haug A, Hostmark AT, Harstad OM. Bovine milk in human nutrition: a review. Lipids Health Dis. 2007;6:25-41.

58. Saxena S, Katare C. Evaluation of flaxseed formulation as a potential therapeutic agent in mitigation of dyslipidemia. Biomed J. 2014;37:386-390. 
650 59. Kristensen M, Jensen MG, Aarestrup J, Petersen KEN, Sondergaard L, Mikkelsen MS, et al. Flaxseed dietary fibers lower cholesterol and increase fecal fat excretion, but magnitude of effect depend on food type. Nutr Met. 2012;9:1-8.

60. Martirosyan DM, Miroshnichenko LA, Kulokawa SN, Pogojeva AV, Zoloedov VI. Amaranth oil application for heart disease and hypertension. Lipids Health Dis. 2007;6:14.

61. Ramaprasad TR, Baskaran V, Krishnakantha TP, Lokesh BR. Modulation of antioxidant enzyme activities, platelet aggregation and serum prostaglandins in rats fed spray-dried milk containing n-3 fatty acid. Mol Cell Biochem. 2005;280:9-16.

62. Kumar S, Singh S, Singh AK, Maibam U, Beenam, Upadhyay RC. Growth rate, feed intake and antioxidant enzyme activity in Sahiwal calves supplemented with chromium propionate during winter season. Indian J Dairy Sci. 2015;68(3):252-258. 
Table 1 Ingredients and nutrient composition of broiler starter and finisher diets

\begin{tabular}{|c|c|c|c|c|c|c|c|c|c|c|}
\hline \multirow{2}{*}{$\begin{array}{l}\text { Ingredients } \\
(\mathrm{g} / \mathrm{kg})\end{array}$} & \multicolumn{5}{|c|}{ Broiler Starter } & \multicolumn{5}{|c|}{ Broiler Finisher } \\
\hline & $\mathrm{T} 1$ & $\mathrm{~T} 2$ & $\mathrm{~T} 3$ & $\mathrm{~T} 4$ & $\mathrm{~T} 5$ & $\mathrm{~T} 1$ & $\mathrm{~T} 2$ & $\mathrm{~T} 3$ & $\mathrm{~T} 4$ & T5 \\
\hline Maize & 537 & 535 & 535 & 535 & 535 & 625 & 622 & 622 & 622 & 622 \\
\hline Flaxseed meal & 0.0 & 100 & 100 & 100 & 100 & 0.0 & 100 & 100 & 100 & 100 \\
\hline Soybean & 390 & 290 & 290 & 290 & 290 & 300 & 200 & 200 & 200 & 200 \\
\hline Fish meal & 30 & 30 & 30 & 30 & 30 & 30 & 30 & 30 & 30 & 30 \\
\hline vegetable oil & 14 & 16 & 16 & 16 & 16 & 14 & 16 & 16 & 16 & 16 \\
\hline Limestone & 9 & 9 & 9 & 9 & 9 & 11 & 11 & 11 & 11 & 11 \\
\hline $\mathrm{DCP}^{1}$ & 15.0 & 15.0 & 15.0 & 15.0 & 15.0 & 15.0 & 15.5 & 15.5 & 15.5 & 15.5 \\
\hline Salt & 3 & 3 & 3 & 3 & 3 & 3 & 3 & 3 & 3 & 3 \\
\hline DL-Methionine & 1 & 1 & 1 & 1 & 1 & 1 & 1 & 1 & 1 & 1 \\
\hline Lysine & 0.0 & 0.3 & 0.3 & 0.3 & 0.3 & 0.0 & 0.3 & 0.3 & 0.3 & 0.3 \\
\hline Constant* & 0.765 & 0.765 & 0.765 & 0.765 & 0.765 & 0.765 & 0.765 & 0.765 & 0.765 & 0.765 \\
\hline Chromium (mg/kg) & 0.0 & 0.0 & 0.5 & 1.0 & 1.5 & 0.0 & 0.0 & 0.5 & 1.0 & 1.5 \\
\hline \multicolumn{11}{|c|}{ Nutrient composition (Calculated based on the analyzed values of ingredients) } \\
\hline Crude Protein & 213 & 213 & 213 & 213 & 213 & 185 & 184 & 184 & 184 & 184 \\
\hline M Energy (MJ/kg) & 12.23 & 12.22 & 12.22 & 12.22 & 12.22 & 12.55 & 12.54 & 12.54 & 12.54 & 12.54 \\
\hline Calcium & 10 & 10 & 10 & 10 & 10 & 11 & 11 & 11 & 11 & 11 \\
\hline Available P & 5 & 5 & 5 & 5 & 5 & 4 & 4 & 4 & 4 & 4 \\
\hline Lysine & 13 & 13 & 13 & 13 & 13 & 10 & 10 & 10 & 10 & 10 \\
\hline \multicolumn{11}{|c|}{ Fatty acid profile of diets (\%) } \\
\hline $\mathrm{C} 14: 0$ & 1.70 & 0.12 & 0.12 & 0.12 & 0.12 & 1.81 & 0.12 & 0.12 & 0.12 & 0.12 \\
\hline C16:0 & 31.4 & 8.59 & 8.59 & 8.59 & 8.59 & 33.1 & 9.32 & 9.32 & 9.32 & 9.32 \\
\hline C16:1 & 9.80 & 3.59 & 3.59 & 3.59 & 3.59 & 11.0 & 4.23 & 4.23 & 4.23 & 4.23 \\
\hline C18:0 & 0.0 & 0.07 & 0.07 & 0.07 & 0.07 & 0.21 & 0.19 & 0.19 & 0.19 & 0.19 \\
\hline C18:1 $\omega-9$ & 38.4 & 21.1 & 21.1 & 21.1 & 21.1 & 39.9 & 23.4 & 23.4 & 23.4 & 23.4 \\
\hline $\mathrm{C} 18: 2 \omega-6$ & 15.5 & 23.4 & 23.4 & 23.4 & 23.4 & 11.4 & 22.8 & 22.8 & 22.8 & 22.8 \\
\hline $\mathrm{C} 18: 3 \omega-3$ & 3.20 & 43.1 & 43.1 & 43.1 & 43.1 & 2.6 & 39.9 & 39.9 & 39.9 & 39.9 \\
\hline SFA & 33.1 & 8.78 & 8.78 & 8.78 & 8.78 & 35.12 & 9.63 & 9.63 & 9.63 & 9.63 \\
\hline MUFA $^{2}$ & 48.2 & 24.7 & 24.7 & 24.7 & 24.7 & 50.9 & 27.6 & 27.6 & 27.6 & 27.6 \\
\hline PUFA $^{3}$ & 18.7 & 66.5 & 66.5 & 66.5 & 66.5 & 14.0 & 62.7 & 62.7 & 62.7 & 62.7 \\
\hline
\end{tabular}

*Constant: (0.3\% salt, 0.1\% DL-Methionine, $0.1 \%$ Trace mineral premix, $0.15 \%$ Vitamin premix, $0.015 \%$ Vitamin B complex, $0.05 \%$ Choline chloride, $0.05 \%$ Toxin binder)

Trace mineral mixture $(100 \mathrm{~g})$ : $\mathrm{FeSO}_{4} .7 \mathrm{H}_{2} \mathrm{O}-8 \mathrm{~g}, \mathrm{ZnSO}_{4} .7 \mathrm{H}_{2} \mathrm{O}-10 \mathrm{~g}, \mathrm{MnSO}_{4} . \mathrm{H}_{2} \mathrm{O}-10 \mathrm{~g}, \mathrm{CUSO}_{4} .5 \mathrm{H}_{2} \mathrm{O}-1 \mathrm{~g}, \mathrm{KI}-30 \mathrm{~g}$

Vitamin premix (1 g): Vitamin A-82.5 IU, Vitamin B2-50 mg, Vitamin D3-12000 unit, Vitamin K-10 mg

Vitamin B complex (1 g): Vitamin B1- $8 \mathrm{mg}$, Vitamin B6-16 mg, Vitamin B12-80 mcg, Niacin -120 mg, Calcium panthotheonate-80 mg, Vitamin E 50\% -160 mg, L-lysine-10 mg and DL- Methionine- $10 \mathrm{mg}$

${ }^{1}$ DCP- Di-calcium Phosphate

${ }^{2}$ Monounsaturated fatty acids

${ }^{3}$ Polyunsaturated fatty acids 
Table 2 Effect of dietary flaxseed meal (FSM) and chromium (Cr) supplementation on growth performance of broiler chicken

\begin{tabular}{|c|c|c|c|c|c|c|c|c|c|}
\hline Indices & & $\mathrm{T} 1$ & $\mathrm{~T} 2$ & $\mathrm{~T} 3$ & $\mathrm{~T} 4$ & T5 & SEM & $P$ value & LC \\
\hline \multirow{3}{*}{$\begin{array}{l}\text { Body weight gain } \\
\text { (BWG, g) }\end{array}$} & $0-3$ weeks & $664^{\mathrm{c}}$ & $587^{\mathrm{a}}$ & $630^{\mathrm{b}}$ & $631^{\mathrm{b}}$ & $653^{\mathrm{c}}$ & 6.7 & 0.009 & 0.014 \\
\hline & 4-6 weeks & 1206 & 1179 & 1187 & 1206 & 1213 & 11.1 & 0.095 & 0.105 \\
\hline & 0-6 weeks & 1870 & 1766 & 1817 & 1837 & 1866 & 15.1 & 0.067 & 0.086 \\
\hline \multirow{3}{*}{ Feed intake (g) } & $0-3$ weeks & 861 & 827 & 815 & 809 & 847 & 7.5 & 0.058 & 0.079 \\
\hline & 4-6 weeks & 2540 & 2386 & 2449 & 2442 & 2504 & 22.7 & 0.076 & 0.096 \\
\hline & 0-6 weeks & 3401 & 3213 & 3264 & 3251 & 3351 & 26.8 & 0.091 & 0.112 \\
\hline \multirow{3}{*}{$\begin{array}{l}\text { Feed conversion } \\
\text { ratio }(\mathrm{FCR})\end{array}$} & $0-3$ weeks & $1.30^{\mathrm{a}}$ & $1.41^{\mathrm{b}}$ & $1.29^{\mathrm{a}}$ & $1.28^{\mathrm{a}}$ & $1.30^{\mathrm{a}}$ & 0.012 & 0.006 & 0.011 \\
\hline & 4-6 weeks & 2.11 & 2.02 & 2.06 & 2.06 & 2.06 & 0.015 & 0.078 & 0.095 \\
\hline & 0-6 weeks & 1.82 & 1.82 & 1.79 & 1.77 & 1.80 & 0.009 & 0.093 & 0.119 \\
\hline
\end{tabular}

$\mathrm{T} 1=0 \mathrm{~g} \mathrm{FSM}+0 \mathrm{mg} \mathrm{Cr}, \mathrm{T} 2=100 \mathrm{~g}$ FSM $+0 \mathrm{mg} \mathrm{Cr}, \mathrm{T} 3=100 \mathrm{~g} \mathrm{FSM}+0.5 \mathrm{mg} \mathrm{Cr}, \mathrm{T} 4=100 \mathrm{~g}$ FSM $+1.0 \mathrm{mg} \mathrm{Cr}$, and T5 = $100 \mathrm{~g} \mathrm{FSM}+1.5 \mathrm{mg}$ Cr per $\mathrm{kg}$ diet

Values bearing different superscripts within the row differ significantly; SEM: Standard error of mean; LC: Linear contrast of Cr levels 
Table 3 Effect of dietary flaxseed meal (FSM) and chromium (Cr) on the efficiency parameters of broiler chicken

\begin{tabular}{|c|c|c|c|c|c|c|c|c|c|}
\hline Indices & & $\mathrm{T} 1$ & $\mathrm{~T} 2$ & T3 & T4 & $\mathrm{T} 5$ & SEM & $\mathrm{P}$ value & $\mathrm{LC}$ \\
\hline Production Efficiency & $3^{\text {rd }}$ week & $243^{b}$ & $198^{\mathrm{a}}$ & $233^{\mathrm{b}}$ & $231^{\mathrm{b}}$ & $239^{\mathrm{b}}$ & 4.1 & 0.008 & 0.146 \\
\hline Factor $(\mathrm{PEF})$ & $6^{\text {th }}$ week & 245 & 231 & 242 & 243 & 247 & 3.6 & 0.068 & 0.331 \\
\hline Protein Efficiency Ratio & $0-3$ weeks & $3.62^{\mathrm{b}}$ & $3.33^{\mathrm{a}}$ & $3.63^{b}$ & $3.66^{\mathrm{b}}$ & $3.62^{b}$ & 0.03 & 0.010 & 0.163 \\
\hline \multirow[t]{2}{*}{ (PER) } & 4-6 weeks & 2.57 & 2.67 & 2.62 & 2.67 & 2.62 & 0.02 & 0.105 & 0.253 \\
\hline & $0-6$ weeks & 2.76 & 2.76 & 2.80 & 2.84 & 2.80 & 0.02 & 0.096 & 0.278 \\
\hline Energy Efficiency Ratio & $0-3$ weeks & $26.4^{\mathrm{b}}$ & $24.3^{\mathrm{a}}$ & $26.5^{\mathrm{b}}$ & $26.7^{\mathrm{b}}$ & $26.4^{\mathrm{b}}$ & 0.20 & 0.007 & 0.098 \\
\hline \multirow[t]{2}{*}{ (EER) } & 4-6 weeks & 15.8 & 16.5 & 16.2 & 16.5 & 16.2 & 0.11 & 0.071 & 0.268 \\
\hline & 0-6 weeks & 18.6 & 18.6 & 18.8 & 19.1 & 18.8 & 0.09 & 0.088 & 0.296 \\
\hline
\end{tabular}

$\mathrm{T} 1=0 \mathrm{~g}$ FSM + 0 mg Cr, T2 = 100 g FSM + 0 mg Cr, T3 = 100 g FSM + 0.5 mg Cr, T4 = 100 g FSM + 1.0 mg Cr, and T5 = 100 g FSM + 1.5 mg Cr per kg diet

Values bearing different superscripts within the row differ significantly; SEM: Standard error of mean; LC: Linear contrast of Cr levels 
Table 4 Effect of dietary flaxseed meal (FSM) and chromium (Cr) supplementation on the carcass characteristics* and cost economics of broiler chicken

\begin{tabular}{|c|c|c|c|c|c|c|c|c|}
\hline Indices & $\mathrm{T} 1$ & $\mathrm{~T} 2$ & T3 & $\mathrm{T} 4$ & T5 & SEM & $\mathrm{P}$ value & $\mathrm{LC}$ \\
\hline Live weight (g) & 1774 & 1692 & 1736 & 1754 & 1775 & 15.2 & 0.071 & 0.285 \\
\hline Eviscerated weight & 66.7 & 66.0 & 66.0 & 66.4 & 66.4 & 0.18 & 0.103 & 0.354 \\
\hline Dressed yield & 71.8 & 71.4 & 71.5 & 71.8 & 71.6 & 0.16 & 0.125 & 0.412 \\
\hline Abdominal fat & $1.90^{\mathrm{c}}$ & $1.51^{\mathrm{b}}$ & $1.46^{\mathrm{b}}$ & $1.33^{\mathrm{ab}}$ & $1.11^{\mathrm{a}}$ & 0.051 & 0.019 & 0.021 \\
\hline Drumstick & 9.59 & 9.71 & 9.35 & 9.64 & 9.68 & 0.074 & 0.095 & 0.314 \\
\hline Breast & 16.5 & 16.5 & 16.8 & 16.6 & 16.9 & 0.13 & 0.125 & 0.407 \\
\hline Thigh & 9.24 & 9.06 & 9.28 & 8.86 & 9.03 & 0.067 & 0.085 & 0.335 \\
\hline Cost change (live weight basis) ${ }^{1}$ & $0.0^{\mathrm{a}}$ & $+10.58^{\mathrm{c}}$ & $+8.51^{\mathrm{bc}}$ & $+8.76^{\mathrm{bc}}$ & $+7.72^{\mathrm{b}}$ & 0.82 & 0.025 & 0.021 \\
\hline Cost change (meat yield basis) ${ }^{2}$ & $0.0^{\mathrm{a}}$ & $+9.65^{\mathrm{c}}$ & $+7.47^{\mathrm{bc}}$ & $+7.67^{\mathrm{bc}}$ & $+6.68^{\mathrm{b}}$ & 0.96 & 0.027 & 0.018 \\
\hline
\end{tabular}

$\mathrm{T} 1=0 \mathrm{~g} \mathrm{FSM}+0 \mathrm{mg} \mathrm{Cr}, \mathrm{T} 2=100 \mathrm{~g} \mathrm{FSM}+0 \mathrm{mg} \mathrm{Cr}, \mathrm{T} 3=100 \mathrm{~g} \mathrm{FSM}+0.5 \mathrm{mg} \mathrm{Cr}, \mathrm{T} 4=100 \mathrm{~g} \mathrm{FSM}+1.0 \mathrm{mg}$ Cr, and T5 = $100 \mathrm{~g} \mathrm{FSM} \mathrm{+} 1.5 \mathrm{mg}$ Cr per kg diet

Values bearing different superscripts within the row differ significantly; SEM: Standard error of mean; LC: Linear contrast of Cr levels

* Based on percentage of live weight

${ }^{1}$ Percentage change in feed cost on live weight basis relative to control diet (T1)

${ }^{2}$ Percentage change in feed cost on meat yield basis relative to control diet (T1) 
Table 5 Effect of dietary flaxseed meal and chromium on the sensory quality of broiler chicken meat

\begin{tabular}{|c|c|c|c|c|c|c|c|c|c|}
\hline \multicolumn{2}{|l|}{ Indices } & $\mathrm{T} 1$ & $\mathrm{~T} 2$ & $\mathrm{~T} 3$ & $\mathrm{~T} 4$ & T5 & SEM & $\mathrm{P}$ value & $\mathrm{LC}$ \\
\hline \multirow{5}{*}{$\begin{array}{c}\text { Cooked } \\
\text { meat }\end{array}$} & Colour \& Appearance & 6.1 & 6.2 & 6.2 & 6.0 & 6.5 & 0.06 & 0.105 & 0.326 \\
\hline & Flavour & 6.2 & 6.0 & 6.4 & 6.1 & 6.5 & 0.08 & 0.112 & 0.385 \\
\hline & Texture & 6.5 & 6.2 & 6.2 & 6.0 & 6.1 & 0.08 & 0.107 & 0.357 \\
\hline & Juiciness & 6.0 & 6.3 & 6.1 & 5.9 & 6.2 & 0.09 & 0.124 & 0.437 \\
\hline & Overall acceptability & 6.0 & 6.1 & 6.2 & 5.8 & 6.4 & 0.07 & 0.143 & 0.498 \\
\hline \multirow[t]{2}{*}{ Raw meat } & Colour Score & 4.1 & 4.0 & 4.1 & 4.0 & 4.0 & 0.11 & 0.199 & 0.546 \\
\hline & Odour Score & 4.1 & 4.1 & 4.0 & 4.1 & 4.0 & 0.11 & 0.162 & 0.502 \\
\hline
\end{tabular}


Table 6 Effect of flaxseed meal (FSM) and chromium (Cr) supplementation on fatty acid profile of broiler chicken thigh

\begin{tabular}{|c|c|c|c|c|c|c|c|c|}
\hline $\begin{array}{l}\text { Fatty Acids (\% of } \\
\text { total fatty acids) }\end{array}$ & $\mathrm{T} 1$ & $\mathrm{~T} 2$ & $\mathrm{~T} 3$ & $\mathrm{~T} 4$ & T5 & SEM & $P$ value & $\mathrm{LC}$ \\
\hline C14:0 & 0.41 & 0.37 & 0.38 & 0.33 & 0.36 & 0.035 & 0.109 & 0.314 \\
\hline C16:0 & $25.1^{b}$ & $19.8^{\mathrm{a}}$ & $20.0^{\mathrm{a}}$ & $18.9^{\mathrm{a}}$ & $18.9^{\mathrm{a}}$ & 0.97 & 0.031 & 0.262 \\
\hline C16:1 & 3.73 & 4.23 & 3.96 & 4.17 & 3.82 & 0.26 & 0.090 & 0.071 \\
\hline C18:0 & $13.2^{\mathrm{b}}$ & $5.0^{\mathrm{a}}$ & $6.5^{\mathrm{a}}$ & $4.7^{\mathrm{a}}$ & $5.9^{\mathrm{a}}$ & 1.56 & 0.008 & 0.141 \\
\hline C18:1 $\omega-9$ & $34.9^{\mathrm{a}}$ & $38.8^{\mathrm{b}}$ & $38.4^{\mathrm{b}}$ & $38.5^{\mathrm{b}}$ & $37.8^{\mathrm{b}}$ & 0.71 & 0.024 & 0.263 \\
\hline $\mathrm{C} 18: 2 \omega-6$ & $17.3^{\mathrm{a}}$ & $21.0^{\mathrm{b}}$ & $20.3^{\mathrm{b}}$ & $22.3^{b}$ & $22.0^{\mathrm{b}}$ & 0.96 & 0.019 & 0.098 \\
\hline $\mathrm{C} 18: 3 \omega-3$ & $1.99^{\mathrm{a}}$ & $3.53^{\mathrm{b}}$ & $3.19^{\mathrm{b}}$ & $3.55^{\mathrm{b}}$ & $3.46^{\mathrm{b}}$ & 0.296 & 0.013 & 0.476 \\
\hline C20:1 $\omega-9$ & $1.43^{\mathrm{a}}$ & $3.49^{\mathrm{b}}$ & $3.46^{\mathrm{b}}$ & $3.78^{\mathrm{b}}$ & $4.07^{\mathrm{b}}$ & 0.468 & 0.008 & 0.224 \\
\hline $\mathrm{C} 20: 3 \omega-3$ & $0.58^{\mathrm{a}}$ & $1.42^{\mathrm{b}}$ & $1.35^{\mathrm{b}}$ & $1.33^{b}$ & $1.28^{\mathrm{b}}$ & 0.154 & 0.025 & 0.096 \\
\hline $\mathrm{C} 20: 4 \omega-6$ & 1.40 & 1.41 & 1.39 & 1.43 & 1.40 & 0.017 & 0.089 & 0.368 \\
\hline $\mathrm{C} 20: 5 \omega-3$ & $0.18^{\mathrm{a}}$ & $0.56^{\mathrm{b}}$ & $0.57^{\mathrm{b}}$ & $0.62^{\mathrm{b}}$ & $0.55^{\mathrm{b}}$ & 0.036 & 0.007 & 0.263 \\
\hline $\mathrm{C} 22: 5 \omega-3$ & $0.26^{\mathrm{a}}$ & $0.65^{\mathrm{b}}$ & $0.66^{\mathrm{b}}$ & $0.64^{\mathrm{b}}$ & $0.67^{\mathrm{b}}$ & 0.041 & 0.012 & 0.367 \\
\hline $\mathrm{C} 22: 6 \omega-3$ & $0.19^{\mathrm{a}}$ & $0.41^{\mathrm{b}}$ & $0.43^{\mathrm{b}}$ & $0.40^{\mathrm{b}}$ & $0.44^{\mathrm{b}}$ & 0.029 & 0.016 & 0.174 \\
\hline SFA & $38.7^{\mathrm{b}}$ & $25.1^{\mathrm{a}}$ & $27.0^{\mathrm{a}}$ & $23.9^{\mathrm{a}}$ & $25.2^{\mathrm{a}}$ & 2.52 & 0.004 & 0.086 \\
\hline MUFA & $40.1^{\mathrm{a}}$ & $46.5^{\mathrm{b}}$ & $45.9^{\mathrm{b}}$ & $46.5^{\mathrm{b}}$ & $45.7^{\mathrm{b}}$ & 1.22 & 0.040 & 0.117 \\
\hline PUFA & $21.9^{\mathrm{a}}$ & $29.0^{\mathrm{b}}$ & $27.8^{\mathrm{b}}$ & $30.3^{\mathrm{b}}$ & $29.8^{\mathrm{b}}$ & 1.07 & 0.017 & 0.158 \\
\hline$\omega-3$ PUFA & $3.20^{\mathrm{a}}$ & $6.57^{\mathrm{b}}$ & $6.20^{\mathrm{b}}$ & $6.54^{\mathrm{b}}$ & $6.40^{\mathrm{b}}$ & 0.447 & 0.011 & 0.273 \\
\hline$\omega-6$ PUFA & $18.7^{\mathrm{a}}$ & $22.4^{\mathrm{b}}$ & $21.6^{\mathrm{b}}$ & $23.7^{\mathrm{b}}$ & $23.4^{\mathrm{b}}$ & 0.98 & 0.019 & 0.088 \\
\hline \multicolumn{9}{|c|}{$+1.0 \mathrm{mg} \mathrm{Cr}$, and $\mathrm{T} 5=100 \mathrm{~g} \mathrm{FSM}+1.5 \mathrm{mg} \mathrm{Cr}$ per kg diet } \\
\hline \multicolumn{9}{|c|}{ SFA: Saturated fatty acids, MUFA: Monounsaturated fatty acids, PUFA: Polyunsaturated fatty acids } \\
\hline SEM: Standard error & mean, & C: Line & ontras & Cr lev & & & & \\
\hline
\end{tabular}


Table 7 Effect of flaxseed meal (FSM) and chromium (Cr) supplementation on fatty acid profile of broiler chicken breast

\begin{tabular}{|c|c|c|c|c|c|c|c|c|}
\hline $\begin{array}{l}\text { Fatty Acids (\% of } \\
\text { total fatty acids) }\end{array}$ & $\mathrm{T} 1$ & $\mathrm{~T} 2$ & $\mathrm{~T} 3$ & $\mathrm{~T} 4$ & T5 & SEM & $\mathrm{P}$ value & $\mathrm{LC}$ \\
\hline C14:0 & 0.46 & 0.40 & 0.42 & 0.41 & 0.42 & 0.021 & 0.091 & 0.167 \\
\hline C16:0 & $26.9^{\mathrm{b}}$ & $21.3^{\mathrm{a}}$ & $21.3^{\mathrm{a}}$ & $20.8^{\mathrm{a}}$ & $20.9^{\mathrm{a}}$ & 1.17 & 0.018 & 0.281 \\
\hline C16:1 & 3.70 & 3.48 & 3.47 & 3.58 & 3.59 & 0.121 & 0.087 & 0.376 \\
\hline C18:0 & $17.7^{\mathrm{b}}$ & $10.9^{\mathrm{a}}$ & $10.7^{\mathrm{a}}$ & $10.2^{\mathrm{a}}$ & $11.0^{\mathrm{a}}$ & 1.41 & 0.005 & 0.273 \\
\hline C18:1 $\omega-9$ & $30.9^{\mathrm{a}}$ & $36.4^{\mathrm{b}}$ & $36.8^{\mathrm{b}}$ & $36.4^{\mathrm{b}}$ & $35.9^{\mathrm{b}}$ & 1.09 & 0.027 & 0.138 \\
\hline $\mathrm{C} 18: 2 \omega-6$ & $15.3^{\mathrm{a}}$ & $18.5^{\mathrm{b}}$ & $18.5^{\mathrm{b}}$ & $19.1^{\mathrm{b}}$ & $19.3^{b}$ & 0.73 & 0.018 & 0.097 \\
\hline $\mathrm{C} 18: 3 \omega-3$ & $0.86^{\mathrm{a}}$ & $1.82^{\mathrm{b}}$ & $1.82^{\mathrm{b}}$ & $1.87^{\mathrm{b}}$ & $1.94^{\mathrm{b}}$ & 0.133 & 0.010 & 0.127 \\
\hline$C 20: 1 \omega-9$ & $1.35^{\mathrm{a}}$ & $3.93^{\mathrm{b}}$ & $3.93^{\mathrm{b}}$ & $4.61^{\mathrm{b}}$ & $3.66^{\mathrm{b}}$ & 0.451 & 0.007 & 0.371 \\
\hline $\mathrm{C} 20: 3 \omega-3$ & $0.37^{\mathrm{a}}$ & $1.14^{\mathrm{b}}$ & $1.14^{\mathrm{b}}$ & $1.02^{\mathrm{b}}$ & $1.20^{\mathrm{b}}$ & 0.154 & 0.037 & 0.185 \\
\hline C20:4 $\omega-6$ & 0.83 & 0.81 & 0.79 & 0.83 & 0.80 & 0.008 & 0.078 & 0.247 \\
\hline $\mathrm{C} 20: 5 \omega-3$ & $0.33^{\mathrm{a}}$ & $0.99^{\mathrm{b}}$ & $1.00^{\mathrm{b}}$ & $0.98^{\mathrm{b}}$ & $1.01^{\mathrm{b}}$ & 0.042 & 0.006 & 0.069 \\
\hline C22:0 & 0.48 & 0.42 & 0.43 & 0.36 & 0.41 & 0.039 & 0.073 & 0.161 \\
\hline $\mathrm{C} 22: 5 \omega-3$ & $0.29^{\mathrm{a}}$ & $0.71^{\mathrm{b}}$ & $0.78^{\mathrm{b}}$ & $0.89^{\mathrm{b}}$ & $1.07^{\mathrm{b}}$ & 0.057 & 0.011 & 0.105 \\
\hline $\mathrm{C} 22: 6 \omega-3$ & $0.26^{\mathrm{a}}$ & $0.59^{\mathrm{b}}$ & $0.61^{\mathrm{b}}$ & $0.69^{\mathrm{b}}$ & $0.86^{\mathrm{b}}$ & 0.042 & 0.018 & 0.162 \\
\hline C24:0 & 1.05 & 0.92 & 0.71 & 0.82 & 0.97 & 0.159 & 0.088 & 0.156 \\
\hline SFA & $46.6^{\mathrm{b}}$ & $31.9^{\mathrm{a}}$ & $31.6^{\mathrm{a}}$ & $30.5^{\mathrm{a}}$ & $31.7^{\mathrm{a}}$ & 2.65 & 0.002 & 0.274 \\
\hline MUFA & $36.0^{\mathrm{a}}$ & $43.8^{\mathrm{b}}$ & $44.2^{\mathrm{b}}$ & $44.6^{\mathrm{b}}$ & $43.2^{\mathrm{b}}$ & 1.10 & 0.006 & 0.095 \\
\hline PUFA & $17.4^{\mathrm{a}}$ & $23.4^{\mathrm{b}}$ & $23.8^{\mathrm{b}}$ & $24.6^{\mathrm{b}}$ & $25.4^{\mathrm{b}}$ & 1.08 & 0.017 & 0.137 \\
\hline$\omega-3$ PUFA & $2.11^{\mathrm{a}}$ & $5.25^{\mathrm{b}}$ & $5.35^{\mathrm{b}}$ & $5.46^{\mathrm{b}}$ & $6.08^{\mathrm{b}}$ & 0.156 & 0.017 & 0.367 \\
\hline$\omega-6$ PUFA & $16.1^{\mathrm{a}}$ & $19.3^{\mathrm{b}}$ & $19.3^{\mathrm{b}}$ & $20.0^{\mathrm{b}}$ & $20.1^{\mathrm{b}}$ & 0.73 & 0.009 & 0.268 \\
\hline
\end{tabular}

$\mathrm{T} 1=0 \mathrm{~g} \mathrm{FSM}+0 \mathrm{mg} \mathrm{Cr}, \mathrm{T} 2=100 \mathrm{~g}$ FSM $+0 \mathrm{~g} \mathrm{Cr}, \mathrm{T} 3=100 \mathrm{~g} \mathrm{FSM}+0.5 \mathrm{mg} \mathrm{Cr}, \mathrm{T} 4=100 \mathrm{~g} \mathrm{FSM} \mathrm{+}$ $1.0 \mathrm{mg} \mathrm{Cr}$, and T5 $=100 \mathrm{~g} \mathrm{FSM}+1.5 \mathrm{mg} \mathrm{Cr}$ per kg diet

SFA: Saturated fatty acids, MUFA: Monounsaturated fatty acids, PUFA: Polyunsaturated fatty acids,

LC: Linear contrast of $\mathrm{Cr}$ levels

SEM: Standard error of mean 
Table 8 Effect of flaxseed meal (FSM) and chromium (Cr) supplementation on fatty acid metabolism of broiler chicken meat

\begin{tabular}{|c|c|c|c|c|c|c|c|c|}
\hline Indices & $\mathrm{T} 1$ & $\mathrm{~T} 2$ & T3 & $\mathrm{T} 4$ & T5 & SEM & P Value & $\mathrm{LC}$ \\
\hline \multicolumn{9}{|c|}{ Thigh } \\
\hline DI (18) & $72.6^{\mathrm{a}}$ & $88.6^{\mathrm{b}}$ & $85.5^{\mathrm{b}}$ & $89.2^{\mathrm{b}}$ & $86.4^{\mathrm{b}}$ & 2.31 & 0.015 & 0.089 \\
\hline DI (16) & $12.9^{\mathrm{a}}$ & $17.6^{\mathrm{b}}$ & $16.5^{\mathrm{b}}$ & $18.1^{\mathrm{b}}$ & $16.8^{\mathrm{b}}$ & 0.77 & 0.024 & 0.071 \\
\hline Total DI & $50.3^{\mathrm{a}}$ & $63.4^{\mathrm{b}}$ & $61.5^{\mathrm{b}}$ & $64.4^{\mathrm{b}}$ & $62.6^{\mathrm{b}}$ & 2.21 & 0.017 & 0.084 \\
\hline Elongase index (EI) & $0.53^{\mathrm{b}}$ & $0.25^{\mathrm{a}}$ & $0.33^{\mathrm{a}}$ & $0.25^{\mathrm{a}}$ & $0.31^{\mathrm{a}}$ & 0.053 & 0.037 & 0.275 \\
\hline Thioesterase index (TI) & $61.6^{\mathrm{b}}$ & $54.7^{\mathrm{a}}$ & $53.4^{\mathrm{a}}$ & $55.2^{\mathrm{a}}$ & $52.6^{\mathrm{a}}$ & 2.80 & 0.073 & 0.078 \\
\hline$\Delta^{5}+\Delta^{6}$-desaturase & $8.54^{\mathrm{a}}$ & $10.99^{\mathrm{b}}$ & $11.51^{\mathrm{b}}$ & $10.68^{\mathrm{b}}$ & $10.72^{\mathrm{b}}$ & $0.590^{\mathrm{b}}$ & 0.079 & 0.096 \\
\hline \multicolumn{9}{|c|}{ Breast } \\
\hline DI (18) & $63.6^{\mathrm{a}}$ & $76.9^{\mathrm{b}}$ & $77.4^{\mathrm{b}}$ & $78.2^{\mathrm{b}}$ & $76.6^{\mathrm{b}}$ & 2.05 & 0.015 & 0.278 \\
\hline DI (16) & $12.1^{\mathrm{a}}$ & $15.3^{\mathrm{b}}$ & $15.2^{\mathrm{b}}$ & $16.0^{\mathrm{b}}$ & $16.0^{\mathrm{b}}$ & 0.27 & 0.024 & 0.386 \\
\hline Total DI & $43.7^{\mathrm{a}}$ & $56.9^{\mathrm{b}}$ & $57.3^{\mathrm{b}}$ & $58.0^{\mathrm{b}}$ & $57.0^{\mathrm{b}}$ & 1.40 & 0.019 & 0.178 \\
\hline Elongase index (EI) & $0.66^{\mathrm{b}}$ & $0.57^{\mathrm{a}}$ & $0.56^{\mathrm{a}}$ & $0.54^{\mathrm{a}}$ & $0.58^{\mathrm{a}}$ & 0.021 & 0.035 & 0.067 \\
\hline Thioesterase index (TI) & $58.9^{\mathrm{b}}$ & $47.8^{\mathrm{a}}$ & $45.6^{\mathrm{a}}$ & $45.5^{\mathrm{a}}$ & $44.5^{\mathrm{a}}$ & 2.746 & 0.064 & 0.095 \\
\hline$\Delta^{5}+\Delta^{6}$-desaturase & $9.57^{\mathrm{a}}$ & $13.25^{\mathrm{b}}$ & $13.55^{\mathrm{b}}$ & $13.89^{\mathrm{b}}$ & $14.99^{b}$ & 0.628 & 0.087 & 0.094 \\
\hline
\end{tabular}

$\mathrm{T} 1=0 \mathrm{~g} \mathrm{FSM}+0 \mathrm{mg} \mathrm{Cr}, \mathrm{T} 2=100 \mathrm{~g} \mathrm{FSM}+0 \mathrm{~g} \mathrm{Cr}, \mathrm{T} 3=100 \mathrm{~g} \mathrm{FSM}+0.5 \mathrm{mg} \mathrm{Cr}, \mathrm{T} 4=100 \mathrm{~g} \mathrm{FSM}+1.0 \mathrm{mg} \mathrm{Cr}$, and T5 = $100 \mathrm{~g}$ $\mathrm{FSM}+1.5 \mathrm{mg}$ Cr per kg diet

DI (18): $\Delta^{9}$-desaturase (18) index, DI (16): $\Delta^{9}$-desaturase (16) index

SEM: Standard error of mean, LC: Linear contrast of Cr levels 
Table 9 Effect of flaxseed meal (FSM) and chromium (Cr) supplementation on health indices of broiler chicken meat

\begin{tabular}{|c|c|c|c|c|c|c|c|c|}
\hline Indices & $\mathrm{T} 1$ & $\mathrm{~T} 2$ & $\mathrm{~T} 3$ & $\mathrm{~T} 4$ & T5 & SEM & $\mathrm{P}$ Value & $\mathrm{LC}$ \\
\hline \multicolumn{9}{|c|}{ Thigh } \\
\hline$\omega-6: \omega-3$ Fatty acid ratio & $5.38^{\mathrm{b}}$ & $3.41^{\mathrm{a}}$ & $3.49^{\mathrm{a}}$ & $3.63^{\mathrm{a}}$ & $3.66^{\mathrm{a}}$ & 0.302 & 0.001 & 0.253 \\
\hline PUFA:SFA Ratio & $0.57^{\mathrm{a}}$ & $1.15^{\mathrm{b}}$ & $1.03^{\mathrm{b}}$ & $1.26^{\mathrm{b}}$ & $1.18^{\mathrm{b}}$ & 0.098 & 0.010 & 0.078 \\
\hline MUFA:SFA Ratio & $1.04^{\mathrm{a}}$ & $1.85^{\mathrm{b}}$ & $1.70^{\mathrm{b}}$ & $1.94^{\mathrm{b}}$ & $1.81^{\mathrm{b}}$ & 0.108 & 0.009 & 0.067 \\
\hline UFA:SFA Ratio & $1.60^{\mathrm{a}}$ & $3.00^{\mathrm{b}}$ & $2.73^{\mathrm{b}}$ & $3.21^{\mathrm{b}}$ & $3.00^{\mathrm{b}}$ & 0.144 & 0.002 & 0.089 \\
\hline Saturation index $(\mathrm{S} / \mathrm{P})$ & $0.62^{\mathrm{b}}$ & $0.33^{\mathrm{a}}$ & $0.37^{\mathrm{a}}$ & $0.31^{\mathrm{a}}$ & $0.33^{\mathrm{a}}$ & 0.054 & 0.021 & 0.276 \\
\hline Atherogenic Index (AI) & $0.43^{\mathrm{b}}$ & $0.28^{\mathrm{a}}$ & $0.29^{\mathrm{a}}$ & $0.26^{\mathrm{a}}$ & $0.27^{\mathrm{a}}$ & 0.017 & 0.017 & 0.351 \\
\hline Thrombogenic Index (TI) & $0.86^{\mathrm{b}}$ & $0.44^{\mathrm{a}}$ & $0.48^{\mathrm{a}}$ & $0.41^{\mathrm{a}}$ & $0.44^{\mathrm{a}}$ & 0.016 & 0.001 & 0.098 \\
\hline DFA $(\%)$ & $75.1^{\mathrm{a}}$ & $80.5^{\mathrm{b}}$ & $80.2^{\mathrm{b}}$ & $81.4^{\mathrm{b}}$ & $81.4^{\mathrm{b}}$ & 0.60 & 0.018 & 0.157 \\
\hline $\operatorname{HFA}(\%)$ & $25.5^{\mathrm{b}}$ & $20.1^{\mathrm{a}}$ & $20.4^{\mathrm{a}}$ & $19.2^{\mathrm{a}}$ & $19.2^{\mathrm{a}}$ & 0.58 & 0.007 & 0.201 \\
\hline $\mathrm{h} / \mathrm{H}$ ratio & $2.23^{\mathrm{a}}$ & $3.37^{\mathrm{b}}$ & $3.25^{\mathrm{b}}$ & $3.58^{\mathrm{b}}$ & $3.51^{\mathrm{b}}$ & 0.107 & 0.006 & 0.064 \\
\hline \multicolumn{9}{|c|}{ Breast } \\
\hline$\omega-6: \omega-3$ Fatty acid ratio & $7.66^{\mathrm{b}}$ & $3.67^{\mathrm{a}}$ & $3.60^{\mathrm{a}}$ & $3.66^{\mathrm{a}}$ & $3.30^{\mathrm{a}}$ & 0.74 & $<0.001$ & 0.441 \\
\hline PUFA:SFA Ratio & $0.37^{\mathrm{a}}$ & $0.74^{\mathrm{b}}$ & $0.75^{\mathrm{b}}$ & $0.81^{\mathrm{b}}$ & $0.80^{\mathrm{b}}$ & 0.060 & 0.010 & 0.162 \\
\hline MUFA:SFA Ratio & $0.77^{\mathrm{a}}$ & $1.37^{\mathrm{b}}$ & $1.40^{\mathrm{b}}$ & $1.46^{\mathrm{b}}$ & $1.36^{\mathrm{b}}$ & 0.101 & 0.010 & 0.085 \\
\hline UFA:SFA Ratio & $1.15^{\mathrm{a}}$ & $2.21^{\mathrm{b}}$ & $2.15^{\mathrm{b}}$ & $2.27^{\mathrm{b}}$ & $2.16^{\mathrm{b}}$ & 0.079 & 0.010 & 0.096 \\
\hline Saturation index $(\mathrm{S} / \mathrm{P})$ & $0.84^{\mathrm{b}}$ & $0.45^{\mathrm{a}}$ & $0.45^{\mathrm{a}}$ & $0.42^{\mathrm{a}}$ & $0.44^{\mathrm{a}}$ & 0.044 & 0.029 & 0.264 \\
\hline Atherogenic Index (AI) & $0.54^{\mathrm{b}}$ & $0.31^{\mathrm{a}}$ & $0.31^{\mathrm{a}}$ & $0.30^{\mathrm{a}}$ & $0.30^{\mathrm{a}}$ & 0.034 & 0.031 & 0.451 \\
\hline Thrombogenic Index (TI) & $1.13^{\mathrm{a}}$ & $0.60^{\mathrm{b}}$ & $0.59^{\mathrm{b}}$ & $0.56^{\mathrm{b}}$ & $0.57^{\mathrm{b}}$ & 0.038 & 0.001 & 0.275 \\
\hline DFA $(\%)$ & $71.2^{\mathrm{a}}$ & $78.5^{\mathrm{b}}$ & $78.7^{\mathrm{b}}$ & $79.3^{\mathrm{b}}$ & $79.5^{\mathrm{b}}$ & 1.02 & 0.013 & 0.313 \\
\hline $\operatorname{HFA}(\%)$ & $27.4^{\mathrm{b}}$ & $19.7^{\mathrm{a}}$ & $19.7^{\mathrm{a}}$ & $19.2^{\mathrm{a}}$ & $19.3^{\mathrm{a}}$ & 0.40 & 0.009 & 0.467 \\
\hline $\mathrm{h} / \mathrm{H}$ ratio & $1.77^{\mathrm{a}}$ & $3.06^{\mathrm{b}}$ & $3.07^{\mathrm{b}}$ & $3.18^{\mathrm{b}}$ & $3.17^{\mathrm{b}}$ & 0.174 & 0.015 & 0.166 \\
\hline
\end{tabular}

$\mathrm{T} 1=0 \mathrm{~g} \mathrm{FSM}+0 \mathrm{mg} \mathrm{Cr}, \mathrm{T} 2=100 \mathrm{~g} \mathrm{FSM}+0 \mathrm{~g} \mathrm{Cr}, \mathrm{T} 3=100 \mathrm{~g} \mathrm{FSM}+0.5 \mathrm{mg} \mathrm{Cr}, \mathrm{T} 4=100 \mathrm{~g} \mathrm{FSM}+$ $1.0 \mathrm{mg} \mathrm{Cr}$, and $\mathrm{T} 5=100 \mathrm{~g} \mathrm{FSM}+1.5 \mathrm{mg} \mathrm{Cr}$ per $\mathrm{kg}$ diet

SFA: Saturated fatty acids, UFA: Unsaturated fatty acids, MUFA: Mono-unsaturated fatty acids, PUFA:

Poly-unsaturated fatty acids,

DFA: Desirable fatty acids, HFA: Hypercholesterolaemic fatty acids,

h/H: hypocholesterolemic/hypercholesterolemic ratio

SEM: Standard error of mean, LC: Linear contrast of Cr levels 
Table 10 The combined effect of flaxseed meal (FSM) and chromium (Cr) supplementation on serum chemistry and health indices of broiler chicken

\begin{tabular}{|c|c|c|c|c|c|c|c|c|}
\hline Attributes & T1 & $\mathrm{T} 2$ & T3 & $\mathrm{T} 4$ & T5 & SEM & $\mathrm{P}$ value & $\mathrm{LC}$ \\
\hline Glucose (g/L) & 2.14 & 2.04 & 1.99 & 1.93 & 1.94 & 0.039 & 0.811 & 0.367 \\
\hline Triglyceride (g/L) & $1.11^{\mathrm{c}}$ & $1.03^{\mathrm{b}}$ & $0.99^{\mathrm{b}}$ & $0.97^{\mathrm{ab}}$ & $0.94^{\mathrm{a}}$ & 0.030 & 0.011 & 0.021 \\
\hline Total cholesterol (g/L) & $1.35^{\mathrm{c}}$ & $1.21^{\mathrm{b}}$ & $1.16^{\mathrm{ab}}$ & $1.13^{\mathrm{ab}}$ & $1.07^{\mathrm{a}}$ & 0.047 & 0.021 & 0.016 \\
\hline HDL cholesterol (g/L) & $0.73^{\mathrm{a}}$ & $0.82^{\mathrm{b}}$ & $0.84^{\mathrm{b}}$ & $0.89^{\mathrm{bc}}$ & $0.93^{\mathrm{c}}$ & 0.033 & 0.011 & 0.014 \\
\hline $\mathrm{SOD}(\mathrm{U} / \mathrm{mL})$ & $112.1^{\mathrm{b}}$ & $141.4^{\mathrm{e}}$ & $136.6^{\mathrm{d}}$ & $123.9^{c}$ & $101.2^{\mathrm{a}}$ & 2.82 & 0.007 & 0.004 \\
\hline Catalase $(\mathrm{nmol} / \mathrm{min} / \mathrm{mL})$ & $51.2^{\mathrm{b}}$ & $68.1^{\mathrm{d}}$ & $70.6^{\mathrm{d}}$ & $60.1^{\mathrm{c}}$ & $41.9^{\mathrm{a}}$ & 2.02 & 0.001 & $<0.001$ \\
\hline GPx (nmol/min/mL) & $10.7^{\mathrm{b}}$ & $14.4^{\mathrm{e}}$ & $14.1^{\mathrm{d}}$ & $12.4^{\mathrm{c}}$ & $9.1^{\mathrm{a}}$ & 0.38 & 0.002 & 0.001 \\
\hline $\mathrm{GR}(\mathrm{nmol} / \mathrm{min} / \mathrm{mL})$ & $13.1^{\mathrm{b}}$ & $15.9^{\mathrm{d}}$ & $15.8^{\mathrm{d}}$ & $14.3^{\mathrm{c}}$ & $11.4^{\mathrm{a}}$ & 0.32 & $<0.001$ & $<0.001$ \\
\hline TBARS Value (MDA $\mu \mathrm{M})$ & $4.28^{\mathrm{b}}$ & $6.94^{\mathrm{e}}$ & $6.78^{\mathrm{d}}$ & $5.55^{\mathrm{c}}$ & $3.18^{\mathrm{a}}$ & 0.270 & 0.009 & 0.006 \\
\hline Cardiac Risk Ratio (CRR) & $1.84^{\mathrm{d}}$ & $1.48^{\mathrm{c}}$ & $1.41^{\mathrm{c}}$ & $1.27^{\mathrm{b}}$ & $1.16^{\mathrm{a}}$ & 0.053 & 0.003 & $<0.001$ \\
\hline Atherogenic Coefficient (AC) & $0.84^{\mathrm{d}}$ & $0.48^{\mathrm{c}}$ & $0.41^{\mathrm{c}}$ & $0.27^{\mathrm{b}}$ & $0.16^{\mathrm{a}}$ & 0.033 & 0.022 & 0.003 \\
\hline Atherogenic Index of Plasma (AIP) & $0.18^{\mathrm{c}}$ & $0.10^{\mathrm{b}}$ & $0.07^{\mathrm{b}}$ & $0.02^{\mathrm{a}}$ & $0.02^{\mathrm{a}}$ & 0.011 & 0.007 & 0.012 \\
\hline
\end{tabular}

$\mathrm{T} 1=0 \mathrm{~g} \mathrm{FSM}+0 \mathrm{mg} \mathrm{Cr}, \mathrm{T} 2=100 \mathrm{~g} \mathrm{FSM}+0 \mathrm{~g} \mathrm{Cr}, \mathrm{T} 3=100 \mathrm{~g} \mathrm{FSM}+0.5 \mathrm{mg} \mathrm{Cr}, \mathrm{T} 4=100 \mathrm{~g} \mathrm{FSM}+1.0 \mathrm{mg}$ Cr, and T5 = $100 \mathrm{~g} \mathrm{FSM} \mathrm{+} 1.5 \mathrm{mg}$

Cr per kg diet

SOD: Super Oxide Dismutase; GPx: Glutathione Peroxidase; GR: Glutathione Reductase; TBARS: Thiobarbituric acid reactive substances;

MDA: Malondialdehyde

SEM: Standard error of mean, LC: Linear contrast of Cr levels 